\title{
Chapter
}

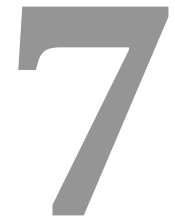

\section{BIODEGRADABLE POLYMERS FOR DENTAL TISSUE ENGINEERING AND REGENERATION}

Raffaele Conte1, Adriana De Luise ${ }^{1}$, Orsolina Petillo² ${ }^{2}$ Carlo Rengo ${ }^{3}$, Francesco Riccitiello ${ }^{3}$, Anna Di Salle1, Anna Calarco, ${ }^{1 *}$ and Gianfranco Peluso ${ }^{1}$

${ }^{1}$ Institute of of Agro-environmental and Forest Biology (IBAF)

${ }^{2}$ Institute of Bioscinece and BioResources, CNR, Naples, Italy

${ }^{3}$ Department of Neurosciences, Reproductive and Odontostomatological Sciences, University of Naples "Federico II", Naples, Italy 


\section{Contents}

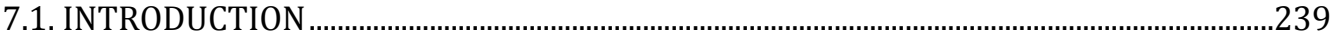

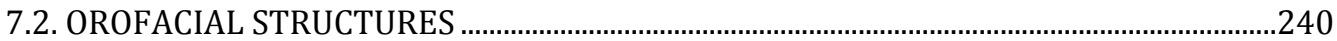

7.3. PATHOLOGICAL ALTERATIONS OF THE OROFACIAL REGION..........................................242

7.4. RESTORATIVE APPROACHES TO PATHOLOGICAL ALTERATIONS....................................244

7.5. DENTAL REGENERATIVE THERAPY ...................................................................................248

7.6. HYDROLYTICALLY DEGRADABLE POLYMERS .....................................................................249

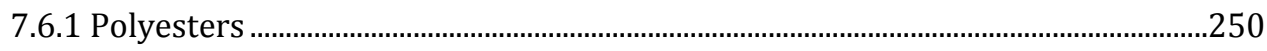

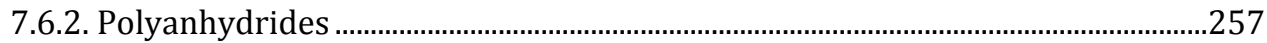

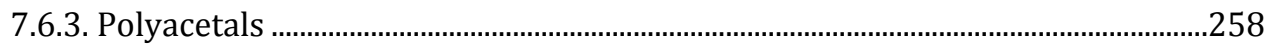

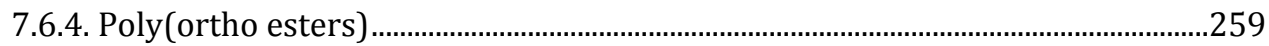

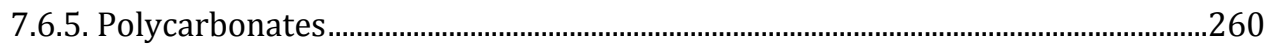

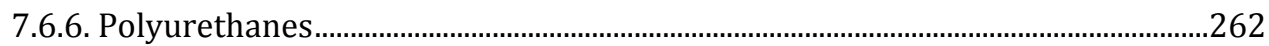

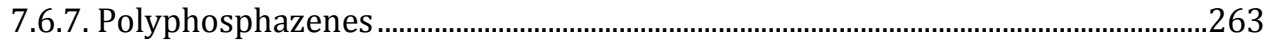

7.7. ENZYMATICALLY DEGRADABLE POLYMERS ………......................................................264

7.7.1. Synthetic polyethers ................................................................................................26

7.7.2. Proteins and poly(amino acids)................................................................................26

7.7.3. Polysaccharides ...........................................................................................................2

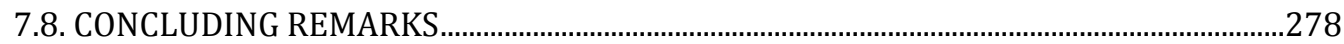

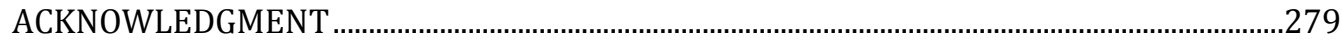

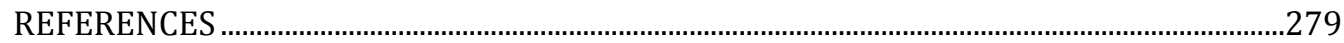




\subsection{INTRODUCTION}

Over the last decade, biodegradable polymers have replaced traditional non-degradable polymers in widespread applications in biomedical areas used for sutures, implantable materials, drug delivery systems, substrates for tissue engineering, and so forth. Compared to other implant materials, such as metals, biodegradable polymers degrade in vivo, by either enzymatic, microbial, or chemical process producing non-toxic byproducts [1-5]. The biomedical biodegradable materials must be carefully designed to achieve the need of the medical applications: (a) not eliciting an inflammatory response; (b) possessing a degradation time coinciding with their function; (c) having appropriate mechanical properties for their intended use; (d) producing nontoxic degradation products that can be readily resorbed or excreted; and (e) including appropriate permeability and processability for designed application [6]. Currently, there is no a single material that satisfies all of these characteristics. Therefore, researchers can design and synthetize materials that match with desired biomedical function changing material chemistry, molecular weight, hydrophobicity, surface charge, water adsorption, degradation, and erosion mechanism [7-8]. Based on their origin, biodegradable polymers can be common classified as natural and synthetic materials. Natural biodegradable polymers are obtained from living organisms (i.e., bacteria) as intra- or extra- cellular products. Natural-based materials include polysaccharides (starch, alginate, chitosan, and hyaluronic acid derivatives) or proteins (soy, collagen, fibrin, gels, and silk) and polynucleotides (DNA, RNA). Synthetic biodegradable polymers are often synthetized by condensation reactions, ring opening polymerization, or metal catalysts and offer greater advantages than natural materials due to a wider range of properties and more predictable lot-to-lot uniformity. Synthetic biodegradable polymer includes poly(lactic acid) (PLA), poly(glycolic acid) (PGA), poly(lactic-co-glycolide) (PLGA) copolymers, and polycaprolactone (PCL). Nowadays, biodegradable materials play an important role in dental or maxillofacial surgery above all for bone regeneration and periodontal disease even if they were originally developed for other applications [9]. In particular, the dental practice over the past fifty years used a restorative approach that involves the restoring of the integrity of missing tooth structure without producing a fully functioning and structurally acceptable regenerated tissue. This approach has indicated the predominant use of metal implants and associated polymeric devices with little thought offered to the effects on local tissues. The novel regenerative approach, instead, aims to recover tooth physiological functions through the selective removal of infected tissue and the use of biodegradable materials acting as scaffold for transplanted stem cells, recruitmentof endogenous stem cells, and release of bioactive molecules, leaving cells to function in an appropriate manner to produce the required 
extracellular matrix (ECM) and ultimately a tissue of a desired geometry, size, and composition [10]. Clinically, tooth loss can result from dental caries, periodontal disease, trauma, congenital anomalies, or chronic diseases. Restoration often experiences the formation of gaps between the prosthesis and natural tissue, leading to bacterial infiltration and development of secondary caries. In this context, dental regenerative therapies promote complete biological recovery of tooth components, favoring the treatment of the most prevalent chronic orofacial diseases (gingivitis, periodontitis, and caries) [11].

\subsection{OROFACIAL STRUCTURES}

The periodontium (Figure 1) is the set of tissues supporting and investing the tooth and comprises dentogingival junction, root cementum, periodontal ligament, and alveolar bone. Each of these components has its specialized structure and defined function. Indeed, proper functioning of the periodontium is only achieved through structural integrity and interaction between its components [12]. The dentogingival junction is an adaptation of the oral mucosa that comprises epithelial and connective tissue components. This structure is essential to seal off periodontal tissues from the oral environment, maintaining a healthy condition. The junctional epithelium is an association of non-differentiated, stratified squamous cells with high turnover that surrounds the tooth connecting it to the gingival connective tissue [13]. The connective tissues form the greater part of the gingivae and contain an extensive vascular plexus where inflammatory cells extravasate [14] and instructive signals exist [15]. The root cementum is a hard, avascular connective tissue that coats the roots of teeth attaching the principal periodontal ligament fibers. It exists in two forms: the primary cementum, important in tooth attachment, that develops very slowly and has a degree of mineralization of about $45-60 \%$, and the secondary cementum, characterized by the presence of cementoblasts entrapped in lacunae within the matrix with repairing functions on resorptive defects and root fractures [16,17]. The periodontal ligament is a specialized connective tissue situated between the cementum covering the root of the tooth and the bone forming the alveolodental ligament, aimed to support the teeth in their sockets and allow them to withstand the forces of mastication. Moreover, the periodontal ligament acts as sensory receptor for the proper positioning of the jaws during mastication and is a cell reservoir for tissue homeostasis and repair/regeneration. The periodontal ligament consists of fibroblasts, epithelial cell rests of Malassez, undifferentiated mesenchymal cells, osteoblasts, osteoclasts, monocytes, macrophages, cementoblasts, odontoclasts, and an extracellular compartment comprising collagenous and noncollagenous matrix constituents. The cells are responsible for proteins and collagen synthesis and secretion, along with periodontal repair/regeneration [18]. Moreover, mesenchymal cells are involved in the restoring of lost bone 
and cementum [19]. The matrix compartment is arranged in definite and distinct fiber bundles that adapt to the continual stresses placed on them and associate with vascular and neural elements to regulate vascular flow in relation to tooth function. Further, the noncollagenous matrix proteins include alkaline phosphatase [20], proteoglycans [21], and glycoproteins such as undulin, tenascin, and fibronectin [22] with a significant effect on the tooth's ability to withstand stress loads. The alveolar bone is the portion of the jaws containing the sockets (alveoli) for the teeth. It consists of outer cortical plates (buccal, lingual, and palatal) of compact bone, a central spongiosa, and bones lining the alveolus (alveolar bone) that provide attachment for the periodontal ligament fiber bundles. The cortical plates consist of lamellae of fine-fibered bone while spongy bones also contain yellow marrow, rich in adipose cells [23]. The tooth, defined as the structure supported by the periodontium, is divided into crown (upper portion) and dental root (bottom portion), linked with a boundary zone called neck. The bulk of the dental hard tissue is dentin, which covers the dental pulp of the core. Enamel is the outer layer that surrounds the dentin in the crown area and cementum is the outer layer of the root area [24]. Specifically, the enamel is the hardest tissue in the body made up of $96 \mathrm{wt} \%$ inorganic materials, for the main part carbonated hydroxyapatite (HA) crystals and with traces of sodium, magnesium, chlorine, carbonate, potassium, and fluoride [24]. The enamel has an acellular and avascular structure, able to remineralize but without the capability to regenerate or repair itself. Dentin is hydrated tissue consisting of $50 \mathrm{vol} \%$ of carbonated HA minerals, $30 \mathrm{vol} \%$ of collagen and noncollagenous molecules, and $20 \%$ of water [24]. Cementum is a mineralized avascular connective tissue, similar in composition to bone composed of $65 \mathrm{wt} \%$ of carbonated HA minerals, $23 \mathrm{wt} \%$ of organic matrix, and $23 \mathrm{wt} \%$ of water. The organic substance consists in proteoglycans and glycoproteins for the amorphous part and in collagen fibers for the structured one [24]. Dental pulp is a mucous connective tissue composed of amorphous gelatinous ground substance rich in glycoproteins, proteoglycans, and glycosaminoglycans (mostly hyaluronic acid). The dental pulp is the best cell source for tissue engineering, since it is a rich reservoir of stem cells residing in various areas (mainly in the root) and having numerous plasticity characteristics [25]. 


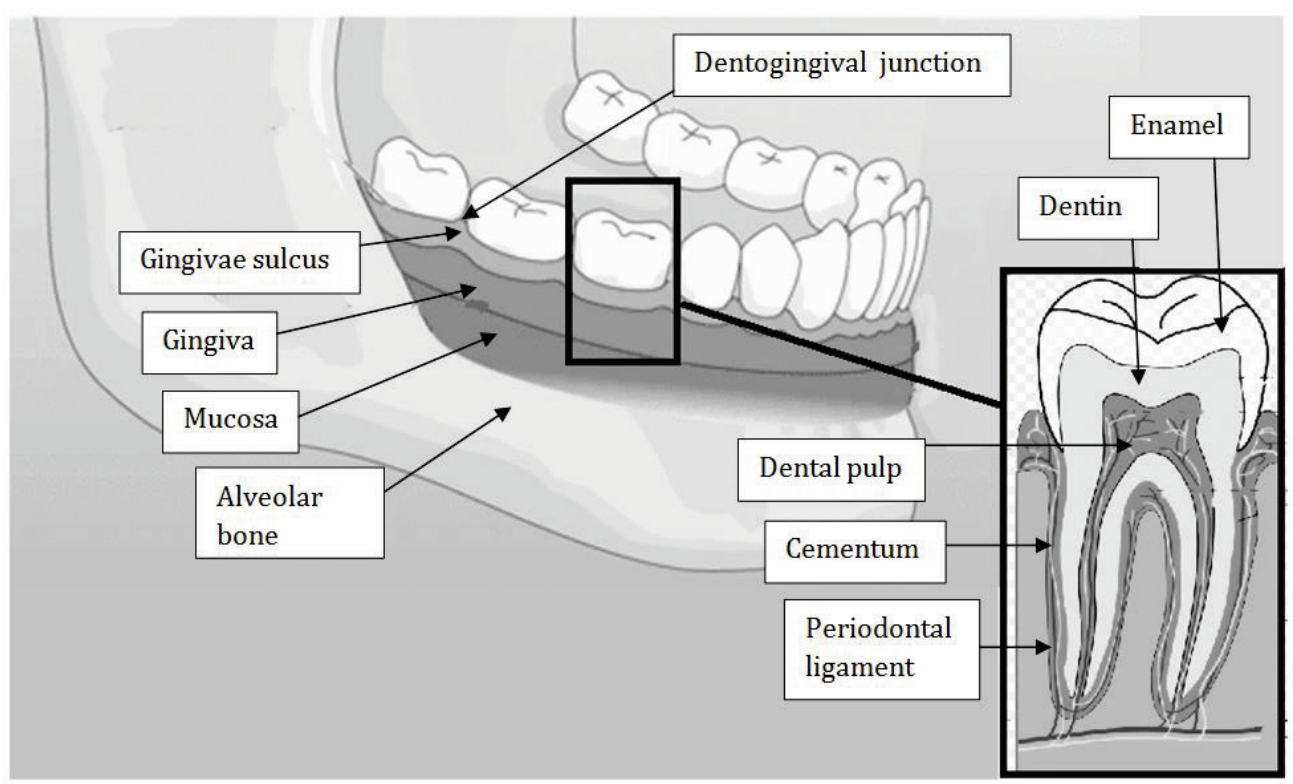

Figure 1. Orofacial structures

\subsection{PATHOLOGICAL ALTERATIONS OF THE OROFACIAL REGION}

Diseases affecting teeth, gingival, and bone tissues are frequent and afflict a high percentage of the worldwide population. The American Association for Dental Research reports that $48 \%$ of adults aged 35-44 years have inflammation of the gingiva (gingivitis) and $22 \%$ destructive periodontal disease, that is, a major cause of tooth loss [26]. Indeed, chronic periodontal diseases are linked with major systemic illnesses such as cardiovascular and pulmonary pathologies, diabetes mellitus, osteoporosis, and adverse pregnancy outcomes [27,28]. Gingivitis and periodontitis have a common series of underlying events leading to tissue breakdown and tooth attachment loss. Specifically, periodontal pathogens, such as Porphyromonas gingivalis, perturb the integrity of the junctional epithelium allowing subgingival spread of bacteria and their antigens. The most frequently identified periodontal pathogens include microaerophilic species (i.e., Actinobacillus actinomycetemcomitans, Campylobacter rectus, and Eikenella corrodens) and anaerobic species (i.e., Porphyromonas gingivalis, Bacteroides forsythus, Treponema denticola, Prevotella intermedia, Fusobacterium nucleatum, Eubacterium, and spirochetes) [29]. The ensuing inflammatory response leads to the degradation of the underlying connective tissue, resulting in the structural and functional disintegration of the gingiva. This structural 
alteration changes the direction of neutrophil migration and increases the size of epithelium free surface leading to an increased risk of bacterial plaque. Moreover, when gingivitis sets, the connective tissue bordering the junctional epithelium is altered by the inflammatory response and is not capable of signaling the epithelium to stop its downward movement. However, the major problem linked with gingivitis and periodontitis is the exacerbating of the host's immune response to counteract bacterial infection. B-lymphocytes, Tlymphocytes, and inflammatory mediators produce a number of proinflammatory cytokines and growth factors, in particular IL-1 and tumor necrosis factor- $\alpha$ (TNF- $\alpha$ ) that are associated with bone resorption through the activation of cells of the osteoclast lineage [30,31]. Further, there is an increased expression of matrix metalloproteinases that destroy collagen [32]. Another diffused alteration of orofacial tissues is the dental decay, a dissolution of tooth mineral (primarily hydroxyapatite $\left.\left(\mathrm{Ca}_{10}\left(\mathrm{PO}_{4}\right)_{6}(0 \mathrm{H})_{2}\right)\right)$ by acids derived from bacterial fermentation of sucrose and other dietary carbohydrates. In fact, teeth surface is coated by an acquired pellicle, which consists of lipids and proteins, including salivary glycoproteins. Primary colonizing bacteria that express receptors for glycoproteins, such as Streptococcus oralis, Streptococcus mitis, Streptococcus gordonii, and Streptococcus sanguis, recognize the pellicle forming an initial biofilm of few layers that gradually grow with the appearance of later colonisers (e.g., gram negative cocci, Lactobacillus casei, and Actinomyces) to create the dental plaque [33]. However, in tooth decay, the fermentable carbohydrates stimulate the metabolic activity of the biofilm bacteria and generate $\mathrm{pH}$ variation in its fluid. When the $\mathrm{pH}$ of saliva is below a critical value of 5.5, tooth enamel demineralizes allowing the microorganisms penetrate into the enamel crystals as the lesion progresses [33]. Dental decay can be classified into primary caries when the lesions occur for the first time in a healthy tooth and secondary caries when the lesions develop adjacent to existing restoration sites [34]. Clinically, dental decay starts with a subsurface demineralization that can only be detected microscopically that evolves in a detectable subsurface lesion known as a white spot. The final stage is a cavitation on the tooth surface [33]. In Figure 2 was summarized the etiology of orofacial pathologies. 


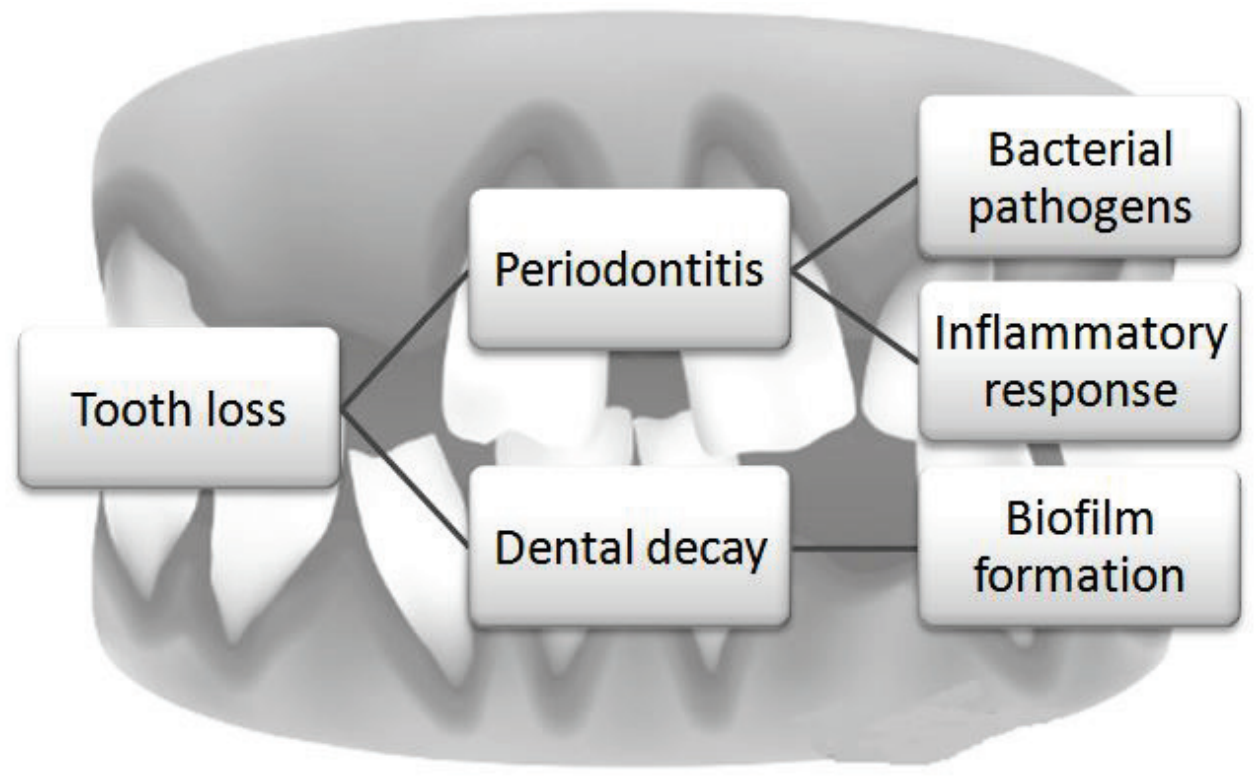

Figure 2. Etiology of orofacial pathologies

\subsection{RESTORATIVE APPROACHES TO PATHOLOGICAL ALTERATIONS}

The classical restorative therapeutic approaches for orofacial diseases include extrinsic dental interventions (e.g., tooth filling, tooth extraction) and implantation of inert, artificial substitutes (e.g., metal, ceramic) [35]. In particular, the selective removal of infected tissues and the preservation of healthy cells structures serve as solid support for a functional, efficient, durable, and integrated restoration [36,37]. Specifically, "flap surgery" (or pocket reduction surgery) consists of tiny incisions to lift back a section of gum tissue exposing the roots for more effective scaling and root planning, "soft tissue graft," has a small amount of tissue removed from the roof of the palate and attached to the affected site in order to reduce gum recession, cover exposed roots, and give a more pleasing appearance to the teeth, and "bone grafting" applies small fragments of synthetic or donated dental bone to the damaged site to hold the tooth in place and serve as a platform for the regrowth of natural bone. Moreover, "guided tissue regeneration" uses biocompatible membranes (both resorbable or not) placed between existing bone and teeth to prevent unwanted tissue from entering the healing area, and "enamel matrix derivative application" involves the application, to a diseased tooth root, of a special gel containing the same proteins found in developing tooth enamel in order to stimulate the growth of healthy bone and tissues [38]. 
Similarly, tooth restorations include fillings, inlays, and crowns to repair damage to individual teeth and bridges, partial dentures, complete dentures, and implants, to protect the shape and function of the mouth as a whole. Fillings are liquid or soft solid materials used to pervade and repair the damage caused by tooth decay. Inlays have a similar function but they are shaped outside the patient's mouth and then cemented into place. Crowns are devices made of gold, stainless steel, tooth-coloured porcelain, or resin able to replace the portion of the tooth covered by the enamel. Bridges are nonremovable appliances of one or more artificial teeth anchored on the adjacent teeth. Partial dentures are removable devices used to fill gap left by missing teeth linked to the abutment tooth with a metal clasp. Complete dentures consist of artificial teeth mounted in a plastic base molded to fit the remaining oral anatomy. Implants are hard polymeric or metal fixtures implanted into the bone and anchored in the oral cavity after bone growth. Restorative orofacial devices must be biocompatible and guarantee good resistance and handling [39]. Suitable materials for their production are classified (Table 1):

Porcelains, ceramic elements made by heating clay, generally including kaolin, to temperatures between 1,200 and $1,400{ }^{\circ} \mathrm{C}$ : such compounds are used to fabricate teeth for the anterior part of the mouth and, with the introduction of stronger porcelains together with the development of cementing systems, to construct inlays [40].

Dental amalgams, alloys of mercury with silver and other metals (e.g., tin and copper) used to fill cavities caused by tooth decay: the original formulation of dental amalgams was considerably modified by the addition of copper and zinc, to enhance their physical properties [41].

Acrylic resins, a group of related thermoplastic or thermosetting polymeric substances derived from acrylic acid, methacrylic acid, or other acrylates that are widely diffused to fabricate dentures due to their excellent biocompatibility, aesthetical properties, and easy handling [42]. However, acrylic polymers are susceptible to wear and shrinkage due to the uncomplete conversion of the monomers during polymerization reaction and these phenomena can lead to poor marginal seal and fractures [43].

Composite resins, fillers for tooth cavities made of synthetic monomers able to form the resin matrix (e.g., dimethacrylate), reinforcing fillers (e.g., radiopaque glass, quartz, or silica), chemical agents (to promote the polymerization reaction), and silane [44]: composite resins are the most commercialized materials for restoration, as shown by the widespread utilization of triethylene glycol dimethacrylate (TEGDMA) or urethane dimethacrylate (UDMA) blended with bisphenol-glycidyl methacrylate (bis-GMA) [45].

Inorganic fillers, such as silicon dioxide, quartz in its crystalline state, aluminium oxide $\left(\mathrm{Al}_{2} \mathrm{O}_{3}\right)$, titanium dioxide $\left(\mathrm{TiO}_{2}\right)$, zinc oxide $(\mathrm{ZnO})$, and zirconium oxide $\left(\mathrm{ZrO}_{2}\right)$, that are easy to handle but not immune from marginal 
degradation during time and the consequent gap formation between the tissue/material interface [46].

Fluoroapatites, phosphate minerals formed by fluoride binding to calcium HA used as fillers able to conduct enamel mineralization and interfere with bacterial metabolism and dental plaque acidogenicity [47]: such materials can also remineralize dentin and help prevent secondary caries $[48,49]$.

Glass ionomer cements (GICS) (also referred to as polyalkanoate cements or aluminosilicate-polyacrylic acid cements), glassy powder based on acid soluble calcium fluoroaluminosilicate and polyacrylic acids with copolymers in liquid form used for dental fillings and luting cements, capable of stabilizing teeth calcium-deficient carbonated HA by ion exchange [50]: the carboxylic groups of GICs replace the phosphate ions of the teeth HA surface to establish ionic bonds with calcium ions derived from the partially dissolved crystals [51]. GICs interfere with subgingival biofilm formation, decreasing the irritation of the periodontal tissues [52]. Examples of commercialized GICs are Fuji IX GP, Ketac N100, Dyract eXtra, and Wave [53,54].

Resin-modified glass ionomer cements (RMGICs), formed starting from GICs through acid-base reaction and free radical polymerization mechanisms: RMGICs have highly packed filler composition $(\sim 69 \%)$, of which approximately two-thirds are nanofillers useful to improve thermomechanical properties and to set a controlled release of active principles [55].

Giomers, restorative materials derived from composites and GICs, constituted by a glass core coated with 3 semi-permeable layers that protect the durability and aesthetics of the glass, while allowing ions to travel freely between the glass core and the oral environment. Such materials are often fluoride modified. Giomers are widely used in toothpaste, topic gels, mouth rinse, and fluoridated water [56]. 
Table 1. Restorative materials

\begin{tabular}{|c|c|c|c|c|c|}
\hline Material & Description & Uses & Appearance & Risk/benefits & Ref. \\
\hline Porcelaines & $\begin{array}{c}\text { Ceramic } \\
\text { elements that } \\
\text { are bonded into } \\
\text { place }\end{array}$ & $\begin{array}{l}\text { Fillings, } \\
\text { crowns, } \\
\text { inlays }\end{array}$ & $\begin{array}{l}\text { Tooth } \\
\text { coloured }\end{array}$ & $\begin{array}{l}\text { Brittle. Well } \\
\text { tolerated. Not } \\
\text { harmful. }\end{array}$ & {$[40]$} \\
\hline Amalgams & $\begin{array}{c}\text { Alloys of } \\
\text { mercury with } \\
\text { silver and other } \\
\text { metals. Harden } \\
\text { by chemical } \\
\text { reaction. }\end{array}$ & Fillings. & $\begin{array}{c}\text { Silver } \\
\text { coloured. }\end{array}$ & $\begin{array}{l}\text { Well tolerated. } \\
\text { Rare sensitivity } \\
\text { and allergies. } \\
\text { Not harmful. }\end{array}$ & [41] \\
\hline Acrylic resins & $\begin{array}{l}\text { Thermoplastic } \\
\text { substances able } \\
\text { to cross-link. }\end{array}$ & Dentures. & Transparent. & $\begin{array}{c}\text { Excellent } \\
\text { biocompatibility. } \\
\text { Easy handling. }\end{array}$ & {$[42]$} \\
\hline Composite resins & $\begin{array}{l}\text { Mixtures of } \\
\text { glass filler and } \\
\text { acrylic that } \\
\text { harden by } \\
\text { chemical } \\
\text { reaction }\end{array}$ & $\begin{array}{l}\text { Fillings, } \\
\text { sealants. }\end{array}$ & $\begin{array}{c}\text { Tooth } \\
\text { coloured. }\end{array}$ & $\begin{array}{l}\text { Well tolerated. } \\
\text { Exposure to a } \\
\text { small amount } \\
\text { of estrogen-like } \\
\text { materials. }\end{array}$ & {$[44,45]$} \\
\hline Inorganic fillers & $\begin{array}{l}\text { Metal oxides of } \\
\text { various } \\
\text { elements }\end{array}$ & Fillings. & $\begin{array}{l}\text { Colour of the } \\
\text { metal used. }\end{array}$ & $\begin{array}{c}\text { Easy to handle. } \\
\text { Can have } \\
\text { marginal } \\
\text { degradation } \\
\text { during time. }\end{array}$ & {$[46]$} \\
\hline Fluoroapatites & $\begin{array}{c}\text { Phosphate } \\
\text { minerals } \\
\text { formed by } \\
\text { fluoride binding } \\
\text { to calcium HA. }\end{array}$ & Fillings. & Opaque. & $\begin{array}{l}\text { Well tolerated. } \\
\text { Rare sensitivity } \\
\text { and allergies. } \\
\text { Not harmful. }\end{array}$ & [47-49] \\
\hline Glass ionomers & $\begin{array}{c}\text { Divided into } \\
\text { glass ionomer } \\
\text { cements, Resin- } \\
\text { modified glass } \\
\text { ionomer } \\
\text { cements and } \\
\text { giomers. } \\
\text { Powder } \backslash \text { liquid } \\
\text { mixtures that } \\
\text { harden by } \\
\text { exposure to } \\
\text { light. }\end{array}$ & $\begin{array}{l}\text { Fillings, } \\
\text { sealants, } \\
\text { cements } \\
\text { for crown } \\
\text { and } \\
\text { bridges. }\end{array}$ & Opaque. & $\begin{array}{l}\text { Well tolerated. } \\
\text { Not harmful. } \\
\text { Low resistance } \\
\text { to wear and } \\
\text { fracture. }\end{array}$ & [50-56] \\
\hline
\end{tabular}




\subsection{DENTAL REGENERATIVE THERAPY}

The restorative approach often allows the formation of gaps between the prosthesis and natural tissue, leading to bacterial infiltration and development of secondary caries. Dental regenerative therapies are currently expected as therapeutic innovations to recover tooth physiological functions overcoming dental restorative limits. Dental regeneration began when epithelial/mesenchymal interactions within the developing tooth germ initiate differentiation of a population of ectomesenchymal cells in the dental papilla into odontoblasts. Odontoblast cells are postmitotic and are responsible for the secretion of primary dentine. Following primary dentinogenesis, these odontoblasts remain functional and secrete physiological secondary dentine at a continuing, reduced rate. These cells retain the ability to respond to mild environmental stimuli and upregulate their secretory activity during reactionary dentinogenesis leading to dentinal regeneration [57]. However, a more intensive stimulus may lead to death of the existing odontoblast population and, in such cases, dentin regeneration is mediated by the differentiation of a new generation of odontoblast-like cells from a precursor population during the process of reparative dentinogenesis [58]. The key issue in dental regeneration relates to the implementation of an appropriate environment ("niche") for cells recruitment and complete functional integration [59]. Two alternative regenerative routes are available with the use of these tailored biomaterials (Figure 3). In "tissue engineering" progenitor cells are seeded onto synthetic scaffolds. The cells grow outside the body, become differentiated, and mime naturally occurring tissues. These tissue-engineered constructs are then implanted into the patients to replace diseased or damaged tissues. Differently, the "in situ tissue regeneration" approach involves the use of biomaterials in the form of powders, solutions, or microparticles to stimulate local tissue repair. Bioactive materials release chemicals by diffusion or network breakdown and activate the cells in contact with these stimuli [60]. Then, the critical prerequisite for successful tissue regeneration is an appropriate ECM, as ECM provides physical scaffolding for the cellular constituents and initiates crucial biochemical and biomechanical cues required for tissues morphogenesis, differentiation, and homeostasis [61]. Biodegradable biomaterials used as ECM provide an environment that supports stem cells differentiation in the presence of other cofactors, such as serum-containing cell culture medium or biochemical supplements $[62,63]$. Afterwards, they are eliminated from the body, in order to avoid parenteral storage of long-lasting foreign compounds [64]. Biodegradable polymers established in clinical applications have controlled degradation rate $[64,65]$, avoid the production of byproducts [64], and preserve mechanical and chemical properties $[66,67]$. Materials meeting these requirements and used for periodontal or tooth regeneration $[68,69]$ are classified as hydrolytically and enzymatically degradable [70-73]. 


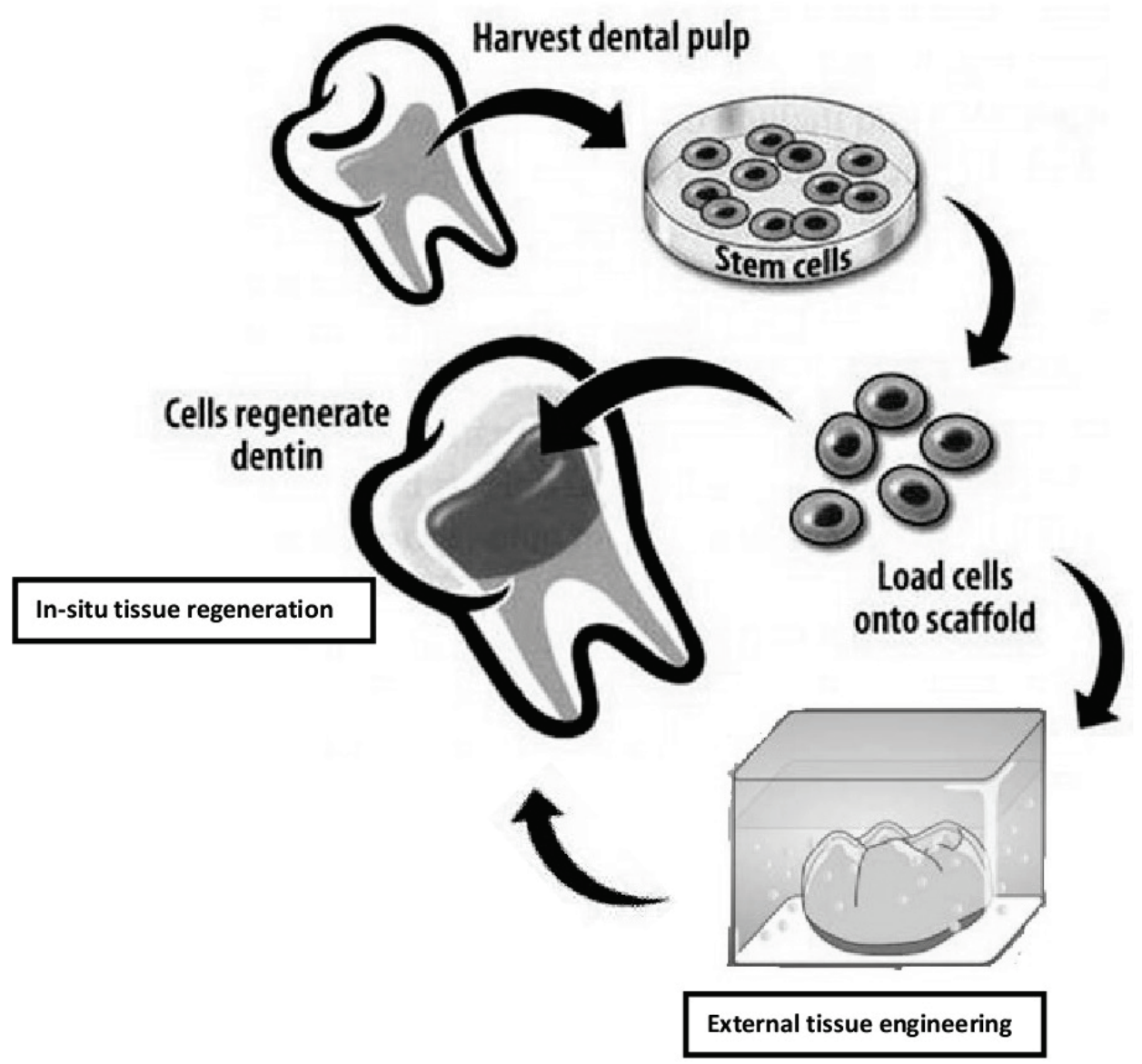

Figure 3. Regenerative routes

\subsection{HYDROLYTICALLY DEGRADABLE POLYMERS}

Polymers with a backbone of hydrolytically labile chemical bonds deteriorate, after water addition, into two species, one with hydrogen atom and the other gaining the hydroxyl group. The degradation rates vary from very hydrolytically unstable materials to extremely hydrolytically stable polymers [74]. However, certain degradation rates can be modulated through chemical substitution. In fact, hydrolytic stability depends on water diffusion, monomer solubility, and device geometry and size. The hydrolytic erosion can involve material surface or the bulk [75]. Surface hydrolysis has greater degradation on the water-device interface compared to the rate at which water diffuses into the bulk. Conversely, bulk erosion is characterized by a faster water diffusion than surface degradation, leading to mass loss occurring throughout the 
material [75]. These categorizations are extremely important in the planning of materials applications. For example, a composite with surface erosion can be used in sustained drug delivery thanks to its ability to maintain tailored payload release kinetics [76], whereas, for applications requiring a permeable membrane like in tissue engineering, bulk eroding materials allow the needed hydrolytic diffusion [77].

\subsubsection{Polyesters}

Polyesters (PE) are a class of polymers that contain aliphatic ester bonds in their backbone. The hydrolytically stable nature of these linkages means that only polyesters with short aliphatic chains can be utilized as degradable polymers for biomedical applications. Moreover, these polymers are mildly hydrophobic and undergo bulk erosion [78]. PE are the most researched degradable biomaterials due to their simple synthesis and commercial availability [79].

Polyglycolide or PGA is one of the first degradable polymers investigated for biomedical use. PGA has melting point $\left(T_{\mathrm{m}}\right)$ greater than $200^{\circ} \mathrm{C}$, glass transition temperature $\left(T_{\mathrm{g}}\right)$ of $35-40^{\circ} \mathrm{C}$, and very high tensile strength (12.5 GPa) [80]. Due to PGA rapid degradation, insolubility in many common solvents, and production of glycolic acid as side product (a substance linked with a strong inflammatory response) [81,82], limited research was conducted with PGA-based drug delivery devices. However, recent papers reported the utilization of PGA as filler material coupled with other degradable polymer networks. Examples are the degradable suture DEXON ${ }^{\circledR}$ [83], the internal bone pin Biofix ${ }^{\circledR}$ [84], many published works in which PGA is used as a scaffold for bone [85-87], cartilage [88,89], tendon [90], vaginal [91], intestinal [92], lymphatic [93], and spinal [94] regeneration. In dentistry, Ohara et al. evaluated the in vivo regeneration of porcine tooth germ-derived cells implanted in polyglycolic acid fiber and $\beta$-tricalcium phosphate porous block scaffolds for the formation of tooth bud-like structures [95]. Similarly, Bäumchen etal. used PGA fleeces to counteract the postoperative apical growth of epithelium on teeth. Such devices were suitable as scaffold structure for human gingival fibroblasts thanks to their significant influence on the proliferation of the cells. In particular, these absorbable textile scaffolds, placed between the operated tooth and its nearby tissues, served as mechanical barrier and prevented undesired apical epithelial growth, allowing new formation of human gingival fibroblasts when the scaffolds were colonized with autologous cells [96].

Polylactide or PLA is a degradable polyester which possesses chiral molecules and comes in four forms: poly(L-lactic acid) (PLLA), poly(D-lactic acid) (PDLA), poly(D,L-lactic acid) (PDLLA; a racemic mixture of PLLA and PDLA), and mesopoly(lactic acid). Among these, only PLLA and PDLLA are extensively studied. PLLA has $T_{\mathrm{g}}$ of $60-65^{\circ} \mathrm{C}$, melting temperature of around $175^{\circ} \mathrm{C}$, and 
mechanical strength of $4.8 \mathrm{GPa}[97,98]$. The additional methyl group in PLA causes the polymer to be much more hydrophobic and stable against hydrolysis, compared to PGA (high molecular weight PLLA requires more than 5 years to be completely resorbed in vivo) [99]. Then, PLLA is modified or copolymerized with other degradable polymers to reduce degradation time, as shown by the use of radiations to create radicals in the ester alpha carbon which, upon rearrangement, shortens the polymer backbone through the removal of an ester bond and the release of carbon dioxide [100,101]. PLLA is used as bone fixator, scaffold for bone [102,103], cartilage [104], tendon [105], neural [106], and vascular [107] regeneration. Similarly, PDLLA is an amorphous polymer with the random positions of its two isomeric monomers within the polymer chain. Poly(D,L-lactic acid) has $T_{\mathrm{g}}$ of $55-60{ }^{\circ} \mathrm{C}$ and mechanical strength of $1.9 \mathrm{GPa}$ [80]. This polyester requires over a year to properly erode and it is commonly used as drug delivery film [108] and tissue engineering scaffold [109-111]. In dentistry, Hile et al. investigated the resorption rate of polylactide-based internal fixation devices. Such devices control the acid generation resulting from the hydrolysis of the polymer and avoid the potential chronic inflammation, also in the presence of osteoconductive buffers [112]. Peltoniemi etal. reviewed the use of PLA bioabsorbable osteofixation devices in craniomaxillofacial surgery. Such devices are applied in the treatment of fractures and osteotomies and find application as self-reinforced materials for internal fixation of the bone [113].

Poly(lactide-co-glycolide) (PLGA) is a polymer derived from the random copolymerization of PLA (both $\mathrm{L}^{-}$and D,L-lactide forms) and PGA. PLGA properties can be modulated through the careful choice of copolymer composition. For example, degradation times of $50: 50$ PLGA, $75: 25$ PLGA, and 85:15 PLGA (LA/GA) are 1-2 months, 4-5 months, and 5-6 months, respectively. PLGA is the most investigated degradable polymer for biomedical applications and is used in sutures, drug delivery devices, and tissue engineering scaffolds. In fact, PLGA 10:90 (Vicryl ${ }^{\circledR}$, Ethicon) and the copolymer LA/GA ratio 90:10 (Panacryl ${ }^{\circledR}$, Ethicon) are used as suture materials [114,115] and microspheres, microcapsules, nanospheres, or nanofibers of PLGA are available to deliver chemotherapeutics $[116,117]$, proteins [118], vaccines [119], antibiotics [120], analgesics [121], antiinflammatory [122], and siRNA [123,124]. Moreover, PLGA demonstrates great cell adhesion and good proliferation properties making it an excellent candidate for application in tissue engineering, as shown by the available scaffolds for the engineering of bone [125,126], cartilage [127], tendon [128] [129], skin [130], liver [131], and nerve tissues [132]. PLGA scaffolds are also used to regenerate damaged tissues in regenerative dentistry, together with stem cell-based therapy. In fact, in a work of Hassan, bone formation was obtained with PLGA carriers incorporated with autogenous bone graft [133] or different bone promoting substances such as the bone morphogenetic protein BMP-2 [134] and simvastatin [135]. PLGA was also used for alveolar ridge 
augmentation through the reconstruction of atrophic sites in association with bone allograft and osteoinductive proteins [136]. In vivo experiments demonstrated how PLGA scaffolds loaded with simvastatin and stromal cell-derived factor- $1 \alpha$ (SDF-1 $\alpha$ ) (an osteoinductive protein) promote bone regeneration significantly more than controls in mouse calvarial defects [137] and how the addition of recombinant human bone morphogenetic proteins to the PLGA-gelatin sponge scaffolds significantly increases bone formation with no immune or other adverse reactions in alveolar ridge augmentation in dogs [138]. Similarly, PLGA/calcium phosphate bilayered biomaterials were employed in class II furcation defects in dogs, resulting in greater periodontal regeneration than traditional flexible membranes [139]. Besides, PLGA/apatite scaffolds [140], PLGA/ $\beta$-tricalcium phosphate scaffolds [141], and beta-tricalcium phosphate particles with rhGDF-5 (enhancer of bone and cement formation) immersed in PLGA [142] were shown to be effective in bone formation. Shirakata et al. demonstrated how PLGA/HA scaffolds promote cell proliferation and differentiation of stem cells [143] and regenerate bone if seeded with differentiated fat cells [144]. Marei et al. used PLGA scaffolds alone or in combination with mesenchymal stem cells or dental pulp stem cells, against maxillary sinus augmentation, obtaining bone regeneration [145]. Another dental application of PLGA relates to the use as guided scaffolds for dental stem cells aimed to create tooth-like structures which are subsequently transplanted in vivo. For example, El-Backly et al. produced, with this method, osteodentine-like structures and tubular bilayered structures of vertically aligned parallel tubules resembling tubular-like dentine in rabbits [146]. Furthermore, PLGA/tricalcium phosphate with tooth bud cells produce dentin-like and pulp-like tissues [147] and PLGA scaffold with stromal cells from the adipose tissue are able to regenerate bones, periodontal ligaments, and cementum layers [148]. PLGA is also used for sustained drug release in endodontics. For example, PLGA microspheres produced by Sousa et al. are able to deliver amoxicillin at significant levels in the root canal [149]. Chitosan coated PLGA microspheres incorporated with recombinant Streptococcus mutans glucan-binding protein $\mathrm{D}(\mathrm{rGbpD})$ are potentially used as dental vaccine [150] and thrombin-loaded poly(D,L-lactide-co-glycolide) microspheres are utilized as a new biodegradable haemostatic device [151]. Periodontology can also profit from the controlled delivery proprieties of PLGA microparticles. In fact, tetracycline [152], doxycycline [153], and chlorhexidine [154] are effectively released locally for periodontal treatment and regeneration. Similarly, PLGA microspheres incorporated with HA and ofloxacin showed good results against $S$. aureus and E. coli [155], while PDLLA-PLGA microparticles filled with growth and differentiation factors accelerate osteogenesis, bone maturation, fibers realignment, and cementogenesis of the periodontal apparatus in rats maxillae [156]. Hong et al. found that the intracellular delivery of estrogen using cationic PLGA microparticles significantly upregulates osteogenic differentiation of human bone marrow mesenchymal stromal cells [157] while PLGA microspheres 
containing simvastatin [158], endothelial growth factors [159], or dexamethasone [160] significantly enhance bone formation. Other applications of PLGA relate to better osteointegration of titanium implants through PLGA microparticles loaded with growth factors [161,162] and the treatment of alveolar bone resorption with bisphosphonate PLGA microspheres [163]. In particular, injectable PLGA microspheres containing fluvastatin enhanced osteogenesis around titanium implants in the rat tibia [164] and PLGA microparticles loaded with insulin improved biomechanical retention of implants on type I diabetic rats [165].

Polyhydroxyalkanoates (PHA) are biodegradable polyesters produced by both bacterial and synthetic routes. The most common polymer of this class is poly(3-hydroxybutyrate) (PHB), a semi-crystalline isotactic material that undergoes surface erosion due to the hydrophobicity of the backbone and its crystallinity [166]. PHB has glass transition temperature of $5{ }^{\circ} \mathrm{C}$ and melting temperature ranging from 160 to $180{ }^{\circ} \mathrm{C}$ [167]. The hydrolytic degradation of PHB results in the formation of $\mathrm{D}-(-)-3$-hydroxybutyric acid that is fully biocompatible, as normal blood constituent [168]. PHB is commonly copolymerized with 3-hydroxyvalerate to create poly(3-hydroxybutyrate)-covalerate (PHBV). PHBV has melting temperature of $80-160^{\circ} \mathrm{C}$ and glass transition temperature in the range of $-5-20^{\circ} \mathrm{C}$, depending on $\mathrm{HV}$ content [169]. PHBV is used in tissue engineering of bone [170], cartilage [171], skin [172], and nerves [173]. PHA are also utilized in association with other polymers [174,175] or modified with additives to enhance their stability $[176,177]$. In dentistry, Ueda et al. inserted medium-chain-length PHA into the defect created in a rabbit's mandible, showing osteoconductive properties which promoted bone regeneration. In particular, space making PHA membranes functioned as permeable barriers useful to shut out the inner growth of soft tissues promoting new bone growth and supplying nutrients. Such membranes degraded when tissues regained their original shape and function [178]. Similarly, Galgul et al. evaluated the histological response of PHBV membranes finding good toleration and little downgrowth of epithelial tissues [179]. Leenstra et al. investigated the use of nonporous PHBV films to keep the mucoperiosteum and bone separated until the completion of the transition of teeth (at about 24 weeks). Compared to PLA or PCL, PHBV films were more suitable for this procedure in terms of mechanical properties and tissue response [180].

Polycaprolactone (PCL) is semi-crystalline polyester with low in vivo degradation rate, melting temperature of $55-60{ }^{\circ} \mathrm{C}$, glass transition temperature of $-54{ }^{\circ} \mathrm{C}$, and high solubility in a wide range of organic solvents [181]. Moreover, it has low tensile strength $(\sim 23 \mathrm{MPa})$, but very high elongation at breakage (4700\%) making it a good elastic biomaterial [81] [182]. PCL is used in the production of implants composed of adhered nano/microspheres [183], electrospun fibers [184,185], or porous networks [186] used for regeneration of bone $[187,188]$, ligament $[189,190]$, cartilage 
[191], nerve [192], and vascular tissues [193]. In addition, PCL is often blended or copolymerized with other polymers like polyesters and polyethers to expedite overall polymer erosion [194]. In dentistry, PCL elicits odontogenic differentiation of human dental pulp cells. In fact, Kim et al. fabricated, by electrospinning, apatite mineralized polycaprolactone nanofibrous scaffolds and compared them with pure polycaprolactone scaffolds. The mineralized polycaprolactone scaffolds improved mineralized nodule formation, expression of odontoblastic marker genes, and growth and odontogenic differentiation of human dental pulp cells, compared to pure PCL scaffolds [195]. Similarly, Chuenjitkuntaworn et al. fabricated a 3D PCL/HA scaffold and studied its ability to support cell growth, gene expression, and osteogenic differentiation of bone marrow-derived mesenchymal stem cells, dental pulp stem cells, and adipose-derived mesenchymal stem cells. The scaffold supported the growth of all of these three types of stem cells and improved calcium deposition [196].

Poly(propylene fumarate) (PPF) is a high strength polyester with the ability to be cross-linked through the unsaturated bonds in its backbone. Then, its degradation depends on molecular weight, cross-linker, and cross-linking density [197]. Physically, PPF is an injectable liquid which becomes solid after cross-linking. PPF is used as filling for bone defects [198] and as depot for the long-term delivery of ocular drugs [199]. Besides, in osteogenic tissue engineering, PPF is used in association with HA [200] or alumoxane [201] to create bioactive scaffolds. In dentistry, Alge et al. produced PPF reinforced dicalcium phosphate dihydrate cement composites to obtain strong materials with mechanical properties suitable for bone tissue engineering. Such scaffolds, implanted into calvarial defects in rabbits for 6 weeks with mesenchymal stem cells, resulted in numerous bone nodules with active osteoblasts within the scaffold pores [202]. Similarly, Shahabi et al. developed degradable poly(propylene fumarate)/bioactive glass (PPF/BG) composite scaffolds based on a microsphere technique and investigated the effects of BG content on the characteristics of these composite scaffolds. The silicon released from the BG enhanced the formation of the calcium phosphate layer of teeth. Moreover, the evaluation of the in vitro degradation of composite microspheres revealed that the weight of scaffolds remains relatively constant during the first 3 weeks and then decreases slowly, losing $10.5 \%$ of their initial mass by week 12, validating their application in tissue engineering [203].

Table 2 acts as summary of polyester based devices used for dentistry. 
Table 2. Polyesters based dentistry devices

Device
PGA fiber and $\beta$-tricalcium phosphate
$\begin{gathered}\text { Pors block scaffolds for the formation of } \\ \text { tooth bud-like structures [95] }\end{gathered}$
PGA fleeces [96]

PLA

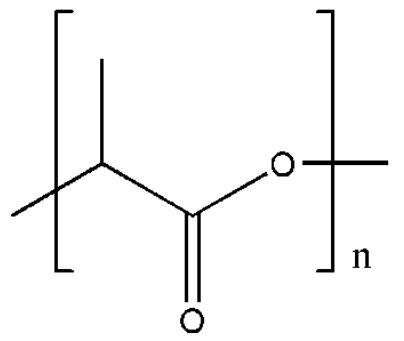

PLA-based internal fixation devices [112]

PLA bioabsorbable osteofixation devices [113]

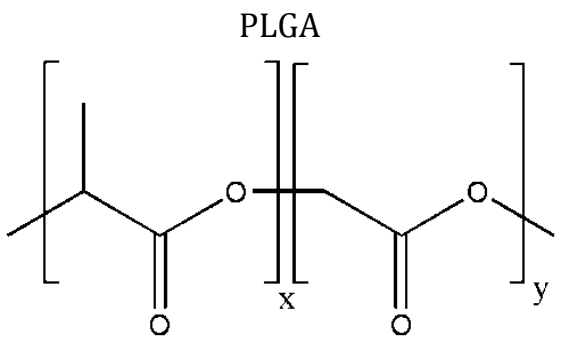

PLGA carriers incorporated with autogenous bone graft [133]

PLGA carriers incorporated with bone promoting substances [134]

PLGA carriers incorporated with simvastatin

PLGA devices for alveolar ridge augmentation [136]

PLGA scaffolds loaded with simvastatin and SDF- $1 \alpha$ [137]

PLGA-gelatin sponge with recombinant human bone morphogenetic proteins [138]

PLGA/calcium phosphate bilayered biomaterials [139]

PLGA/apatite scaffolds [140]

PLGA $/ \beta$-tricalcium phosphate scaffolds [141]

Beta-tricalcium phosphate particles with rhGDF-5 immersed in PLGA [142]

PLGA/HA scaffolds $[143,144]$

PLGA scaffolds with mesenchymal stem cells or dental pulp stem cells against maxillary sinus augmentation [145]

Osteodentine-like PLGA structures [146]

PLGA/tricalcium phosphate with tooth bud 
Table 2. (continued)

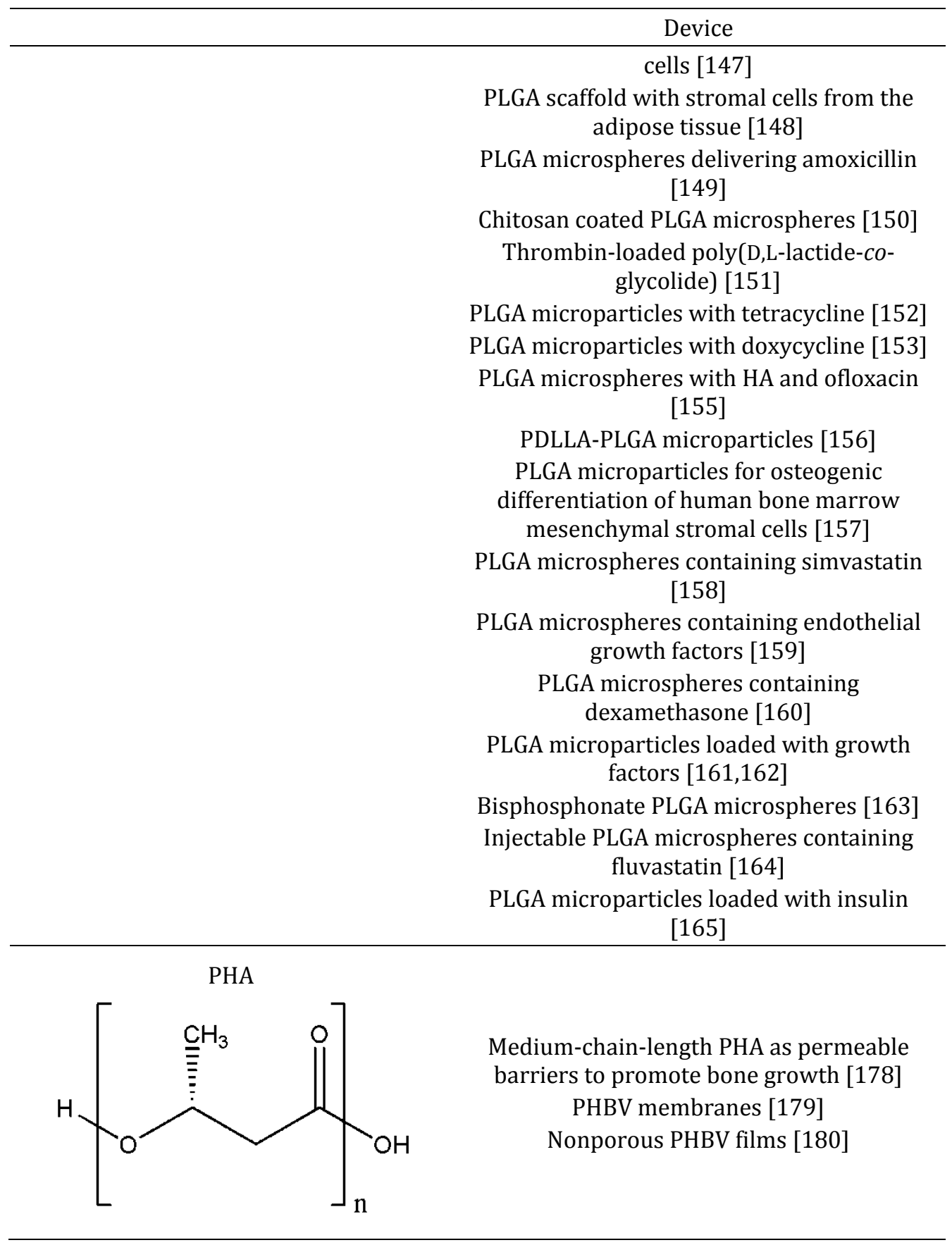


Table 2. (continued)

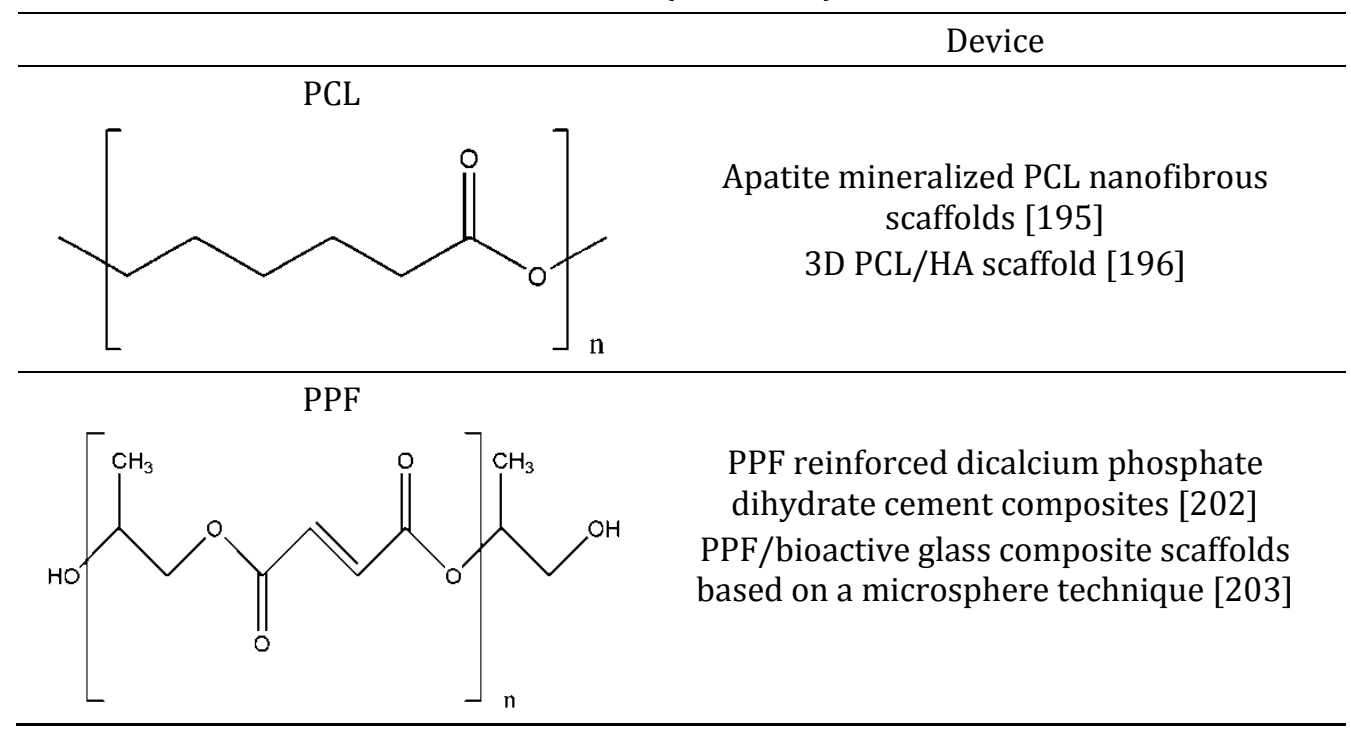

\subsubsection{Polyanhydrides}

Polyanhydrides (PAN) are a class of surface eroding polymers that contain two carbonyl groups linked by an ether bond. The degradation of the anhydride bond is highly dependent on polymer backbone chemistry, ranging by over six orders of magnitude. PAN are used for the delivery of chemotherapeutics [204], antibiotics [205], vaccines [206], and proteins [207]. In particular, simple aliphatic homopolyanhydrides have limited applications due to their rapid degradation. Then, these materials are copolymerized with hydrophobic aromatic diacid monomers [208] or aliphatic fatty acid dimers [209] for drug delivery applications, while methacrylated polyanhydrides and cross-linked PAN are used in tissue engineering [210,211]. In dentistry, Anseth et al. developed a new family of photopolymerizable, methacrylated anhydride monomers and oligomers with PAN that combine high strength, controlled degradation, and photoprocessibility in a single system. These networks have degradation times ranging from 1 week to 1 year and retain up to $90 \%$ of their tensile modulus at $40 \%$ mass loss. In vivo studies in rats resulted in excellent osteocompatibility [212]. Similarly, Hasturk et al. studied the effects of the use of light/chemically hardened polymethyl methacrylate, polyhydroxylethylmethacrylate, and calcium hydroxide graft material in combination with polyanhydride around dental implants and extraction sockets. The histologic evaluations supported the implant stability and confirmed that this device provides a great bone-to-implant contact with a well-organized implant-bone interface, resulting in being effective in crestal augmentation during immediate implant placement [213]. Uhrich patented oral administered polyanhydrides which degrade into biologically active salicylates and alpha-hydroxy acids 
against dental inflammatory pathologies [214]. A subsequent patent of the same author provided PAN linked with low molecular weight drugs containing a carboxylic acid group and an amine, thiol, alcohol, or phenol group within their structure as polymeric drug delivery systems for the same applications [215]. Similarly, Johnson described biodegradable polyanhydrides fabricated into disks, coatings, microspheres, and tubes used as potential treatment for periodontal diseases, orthopedic injuries, nerve regeneration, and biofilm formation, due to the presence of salicylic acid ampicillin in the polymer backbone [216]. Table 3 summarizes PAN based devices used for dentistry.

Table 3. PAN based dentistry devices

\begin{tabular}{c} 
Device \\
$\begin{array}{c}\text { Photopolymerizable, methacrylated anhydride } \\
\text { monomers, and oligomers with PAN for dental tissue } \\
\text { engineering [212] }\end{array}$ \\
$\begin{array}{c}\text { Light/chemically hardened polymethyl methacrylate, } \\
\text { polyhydroxylethylmethacrylate, and calcium } \\
\text { hydroxide graft with polyanhydride around dental } \\
\text { implants and extraction sockets [213] } \\
\text { Oral administered PAN which degrade into } \\
\text { biologically active salicylates and alpha-hydroxy } \\
\text { acids [214] } \\
\text { PAN linked with low molecular weight drugs } \\
\text { containing a carboxylic acid group and an amine, } \\
\text { thiol, alcohol, or phenol group within their structure } \\
\text { [215] } \\
\text { Biodegradable PAN fabricated into disks, coatings, } \\
\text { microspheres, and tubes [216] }\end{array}$ \\
\hline
\end{tabular}

\subsubsection{Polyacetals}

Polyacetals (PA) are degradable polymers in which two ether bonds are connected to the same carbon molecule (geminal). The molecular closeness of the ether bonds, normally stable in water, conveys hydrolytic instability and gives PA surface eroding properties. PA are classified into two subgroups: PA that have only one of the two geminal bonds possessing hydrogen atom and polyketals, with no geminal linkages containing hydrogens. These materials have wide application in biomedical research since their degradation products possess no carboxylic acids, yielding significantly milder $\mathrm{pH}$ microenvironments. Moreover, their erosion is acid-catalyzed [217]. PA microparticles and nanoparticles are used as delivery systems in the treatment of acute inflammatory diseases [218], ischemic heart diseases [219], and cancer and vaccines [220]. For most implant applications, cyclic polyacetal 
homopolymers and those copolymerized with poly(ethylene glycol) (PEG) diacrylate have shown preliminary promise as osteogenic biomaterials for bone tissue engineering [221]. In dentistry, the use of PA is widely diffused in restoration. Fitton et al. described polyacetal injection-moulded resins marketed for the construction of retentive and supportive components of removable partial dentures [222]. The same application was reported by Savion et al. that studied the use of dental D (polyacetal resin) as an alternative for chrome-cobalt removable partial denture [223]. Similarly, Jiao et al. investigated the influence of polyacetal resin supporting components on the load transfer characteristics of unilateral distal extension removable partial dentures. PA focus the highest stresses on the abutment and on the bone, leading to more equitably distributed forces on the traditional metal framework of removable partial dentures [224]. Table 4 lists PA based devices used for dentistry.

Table 4. PA based dentistry devices

\begin{tabular}{ccc}
\hline PA & Device \\
\hline$\left[-\mathrm{CH}_{2}-\mathrm{O}-\mathrm{P}\right.$ & $\begin{array}{c}\text { Polyacetal injection-moulded resins for retentive and } \\
\text { supportive components of removable partial } \\
\text { dentures [222] }\end{array}$ \\
& & Dental D polyacetal resin partial dentures [223] \\
& & Polyacetal based removable partial dentures [224] \\
\hline
\end{tabular}

\subsubsection{Poly(ortho esters)}

Poly(ortho esters) (POE) are substances with three geminal ether bonds. POE are hydrophobic, with surface eroding degradation and controllable backbone chemistry that allows the synthesis of polymers with varied acid-catalyzed degradation rates and properties. In particular, POE incorporating short segments of lactic or glycolic acid into the polymer backbone, in order to expedite degradation, are used for the delivery of analgesics [225], DNA vaccines [226], and antiproliferative drugs [227]. However, POE capacity to be used as tissue engineering scaffolds is limited by their weak mechanical properties and the induction of a mild to moderate inflammatory response [228]. Also in dentistry, POE are mainly used as drug delivery systems. Roskos et al. prepared POE by the condensation of 1,2,6-hexanetriol and an alkyl orthoacetate incorporating tetracycline. Unmodified materials have complete release within about 24 hours while the addition of $\operatorname{Mg}(\mathrm{OH})_{2}$ extended the release to weeks. In addition, these materials are injectable and with dentoadhesive capacity, being useful in the treatment of periodontitis 
[229]. Similarly, Schwach-Abdellaoui et al. produced semisolid POE solutions containing tetracycline free base for the direct injection in the periodontal pocket. Such systems showed sustained release in phosphate buffer, $\mathrm{pH} 7.4$ at $37^{\circ} \mathrm{C}$, for up to 14 days. These POE formulations containing $10 \%$ or $20 \%$ (wt/wt) tetracycline were tested in a panel of 12 patients suffering from severe and recurrent periodontitis, resulting in prolonged retention in the inflamed periodontal pockets and high tetracycline concentrations in the gingival crevicular fluid [230]. Erdmann etal. investigated the effects of degradable poly(anhydride ester) implants in which the polymer backbone breaks down into salicylic acid on new bone formation. These active polymer membranes placed on the palatal bone adjacent to the maxillary first molars resulted in less inflamed tissues, greater thickness of new palatal bone, and no resorptive areas [231]. Table 5 summarizes POE based devices used for dentistry.

Table 5. POE based dentistry devices

$\left.\left.\begin{array}{r}\text { Device } \\ \text { POE incorporating tetracycline }[229,230] \\ \text { POE with } \mathrm{Mg}(\mathrm{OH})_{2} \text { incorporating tetracycline } \\ {[229,230]}\end{array}\right] \begin{array}{r}\text { Degradable poly(anhydride ester) implants in which } \\ \text { the polymer backbone breaks down into salicylic } \\ \text { acid [231] }\end{array}\right]$

\subsubsection{Polycarbonates}

Polycarbonates (PCA) are linear polymers with two geminal ether bonds and a carbonyl linkage. Structurally, such connections are hydrolytically stable but PCA possess rapid surface in vivo degradation, presumably due to enzymatic activity [232]. The most extensively studied polycarbonate is poly(trimethylene carbonate) (PTMC) which has a $T_{\mathrm{g}}$ of $-17^{\circ} \mathrm{C}$, elastomeric characteristics, slow degradation profile, and biocompatible degradation products [233]. PTMC is fabricated into microparticles [234], discs [235], and gels [236] alone or with polyesters or polyethers [237] for the delivery of angiogenic agents [238] and antibiotics [235]. Moreover, PCA with cyclohexane or propylene in the monomer backbone [239] or with bulky side groups linked through an ester bond to the carbons of the backbone [240] are used in tissue 
engineering. Other PCA, used as fixators, are tyrosine-derived PCA. For example, poly(desaminotyrosyltyrosine alkyl ester carbonates) find application in the fabrications of films, fibers, and gels, for bone, vasculature and muscle [241-243]. PCA are materials widely used in dentistry as orthodontic brackets. For example, Feldner et al. investigated the torquedeformation characteristics of pure PCA brackets, ceramic reinforced PCA brackets, metal slot reinforced PCA brackets, and metal slot and ceramic reinforced PCA brackets. Their results show that only the metal slot reinforced brackets are clinically capable of torquing teeth sufficiently [244]. Similarly, Alkire et al. measured the torsional creep of PCA orthodontic brackets. No clinically significant creep was present for metal, ceramic, and metal slot reinforced brackets, while PCA brackets without metal slots demonstrated significantly more creep [245]. PCA are also used as denture resins. For example, Pronych et al. compared the dimensional stability and dehydration of a thermoplastic PCA denture base resin with two conventional polymethyl methacrylate materials. The thermoplastic resin has similar behavior but less dimensional change caused by dehydration [246]. Similarly, Jancar and Dibenedetto used PCA based fiber-reinforced composites for treatment of misaligned teeth. The performance of this material was strongly dependent on the resistance to hydrolytic deterioration of the components. Annealed PCA and maleated polypropylene used as reinforce were found as an appropriate combination of mechanical properties and environmental stability for orthodontic applications [247]. The same authors also studied the effect of moisture on the deterioration of matrix and matrix-fiber interface. No significant reduction in longitudinal properties, controlled by fiber behaviour, resulted from exposure to water, while a significant reduction in transverse properties, controlled by the matrix and interface behaviour, was observed. Moreover, PCA/bare E-glass fiber composite annealed at $275^{\circ} \mathrm{C}$ for $1 \mathrm{~h}$ before immersion in water exhibited superior resistance to moisture attack. Resistance against moisture favours the application as an orthodontic wire of this material [248]. Table 6 is a summary of PCA based devices used for dentistry. 
Table 6. PCA based dentistry devices

Device
PCA brackets [244]
Ceramic reinforced PCA brackets [244]
Metal slot reinforced PCA brackets [244]
Metal slot and ceramic reinforced PCA brackets
[244]
PCA orthodontic brackets [245]
Thermoplastic PCA denture base resin [246]
PCA based fiber-reinforced composites [247]
PCA/bare E-glass fiber composite [248]

\subsubsection{Polyurethanes}

Polyurethanes (PUR) are biocompatible, moldable, strong polymers that possess ester bonds with geminal amide bonds. Such materials are typically synthesized by polycondensation of diisocyanates with alcohols and amines [249]. PUR consist of both hard and soft segments. The hard segments are composed of functional groups (e.g., amide, urea, or ester-amide) able to form hydrogen bonds, making the structure rigid and unable to undergo conformational changes. The soft segments are of polymenthide chains. The repeating monomers are flexible and withstand conformational changes [250]. For these characteristics PUR mime body tissues and are extensively used in prostheses like cardiac assist devices [251], small vascular shunts [252], and tracheal tubes [253]. The same properties are available in PUR reinforced carbon fibers [254]. In the field of dentistry, PUR are tested as arch models able to regulate the position of the teeth [255] and as substitutes of braces for removable dental aligner restorative treatments (e.g., Invisalign) [256-258]. Moreover, Lee and Cho created altered PUR casts for partial removable dental prosthesis that facilitate separation after processing [259]. Selten et al. produced a modified PUR foam as local hemostatic agent after dental extractions [260] while Alter and Fookson used PUR as a dental adhesive system. Specifically, the isocyanate groups in the adhesive react with the tooth mineral. Moreover, the bonding of PUR to enamel is improved by pretreatments (acid etching and acetone drying) and by proper choice of polyol, fillers, and coupling agents [261]. Table 7 lists PUR based devices used for dentistry. 
Table 7. PUR based dentistry devices

PUR based arch models [255]
PUR as braces substitutes for removable
dental aligner restorative treatments [256]
[257]

\subsubsection{Polyphosphazenes}

Polyphosphazenes (PPZ) are degradable polymers characterized by the presence of a completely inorganic backbone consisting of phosphorous and nitrogen bonded linearly through alternating single and double bonds. These polymers are characterized by high physical and chemical flexibility [262]. PPZ are modified through the two phosphorous side groups open to conjugation via esterification, etherification, or amidification, to regulate the degradation rate [263]. For example, side groups like amino acid esters, glucosyl, glyceryl, glycolate, lactate, and imidazole sensitize hydrolysis of the backbone and allow the design of clinically relevant biomaterials. Consequently, thermal and mechanical properties of PPZ greatly vary with $T_{\mathrm{g}}$ ranging from -10 to $35^{\circ} \mathrm{C}$, contact angle $63^{\circ}-107^{\circ}$, tensile strength $2.4-7.6 \mathrm{MPa}$, and modulus of elasticity 31.4-455.9 MPa [264]. PPZ are fabricated into particles, micelles, microneedle coatings, and gels for the delivery of anti-inflammatory drugs, chemotherapeutics, growth factors, DNA, proteins, and vaccines [265-268]. Moreover, PPZ scaffolds composed of films, fibers, and microspheres are used to assist nerve regeneration and orthopedic applications, alone or blended with polyesters to increase mechanical strength and provide a moderate $\mathrm{pH}$ microenvironment for developing tissues [269-271]. In dentistry, PPZ are widely used in removable prosthodontic treatments, systematically blended with a number of additives that are commonly used in other dental products (e.g., acrylic monomers). For example, Razavi et al. described the use of PPZ based resilient denture liners for the treatment of atrophic mandibles, preoperative and postoperative soft tissue management, and retention of removable prosthesis. $\mathrm{PPZ}$ act as retentive material in conventional and implant overdenture rehabilitation [272]. Similarly, Novus ${ }^{\circledR}$ is a PPZ based denture liner that does not need periodic surface coating, is easy to grind, adjust, and polish, and restricts the migration of toxic plasticizers. Ohashi and Anzai used a filling composite material containing 10 to $99 \%$ by weight of phosphazene in which at least one substituent is a radical having not less than 3 carbon atoms and polymerizable, to provide an improved dental filling 
composite material which is not injurious to the pulp and the soft tissues and that forms an eternal prosthesis [273]. Table 8 summarizes the main uses of PPZ in dentistry devices.

Table 8. PPZ based dentistry devices

Device

PPZ

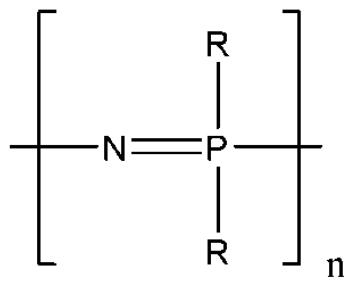

PPZ based resilient denture liners [272]

Filling composite material containing $10-99 \%$ by weight of PPZ [273]

\subsection{ENZYMATICALLY DEGRADABLE POLYMERS}

Enzymatically degradable polymers are materials that possess bonds that require catalysis to undergo meaningful degradation under physiological conditions. Most of these polymers contain ether or amide bonds.

\subsubsection{Synthetic polyethers}

Synthetically derived polyethers (PETH) are highly biocompatible polymers widely used in drug delivery and tissue engineering. PETH are degraded by etherases, also if human equivalents of these enzymes have yet to be identified [274]. Polyether chains are dissociated from the biomaterial and removed via the excretory system. In general, the use of polyethers with low molecular weights due to a near absence of in vivo degradation and the fear of accumulation is recommended. In particular, all biomedical researches with PETH focus on the use of PEG and poly(propylene glycol) (PPG), while a limited amount of work is conducted using poly(tetrahydrofuran). PEG and PPG are also linked in the triblock form of pluronic ([PEG]n-[PPG]m-[PEG]n) [275] that allow the formation of small micelles $(10-100 \mathrm{~nm}$ in diameter) by self-assembly in water for the delivery of chemotherapeutics, antibacterials, antidiuretics, anti-inflammatory drugs, and DNA [275-277]. Pluronic is also formulated into hydrogels with relatively weak mechanical properties (maximum shear storage modulus of $13.7 \mathrm{kPa}$ at $20 \mathrm{wt} \%$ pluronic) used for drug delivery [278] and soft tissue engineering [279]. The mechanical strength of these polyether-based hydrogels is enhanced through cross-linking with 
excess acryloyl chloride or methacryloyl chloride yielding to the hydrogels PEG diacrylate (PEGDA; shear storage modulus of $68 \mathrm{kPa}$ at $20 \mathrm{wt} \%$ ) [280] and PEG dimethacrylate (PEGDMA; shear storage modulus of $125 \mathrm{kPa}$ at $20 \mathrm{wt} \%$ ) [281] that are used in the delivery of chemotherapeutics, hormones, antibacterials, and anti-inflammatory drugs [282] as well as scaffolds in the engineering of cartilage, bone, endothelial, and vascular tissues [283]. PEGDA and PEGDMA are also available in composite systems with other acrylated and methacrylated degradable polymers, most commonly polyesters [284], polyanhydrides [285], and chitosan [286]. In these composites, the polyether diacrylate monomers show the cross-linked network hydrophilicity while the other degradable components convey greater mechanical strength (compressive moduli as great as $\sim 100 \mathrm{MPa}$ ). Finally, PEG is commonly used to cap (PEGylation) or coat other degradable polymers in order to convey steric stabilization limiting the interactions between the device and the host. This is especially important in preventing phagocytosis of particle-based delivery vehicles [287]. In dentistry, poly(ethylene glycol)-like coatings (PEG-like) are used on titanium dental implants for their antifouling activity. In particular, the development of PEG-like coating on the titanium surface by plasma polymerization leads to a surface with low bacterial adhesion and adequate cell response. In fact, in a work of Buxadera-Palomero et al., Streptococcus sanguinis and Lactobacillus salivarius showed decreased adhesion on the plasma polymerized samples, while cell adhesion of fibroblasts and osteoblasts on the treated surfaces was similar to control surfaces [288]. PEG was also used by Dabbagh et al. to coat maghemite nanoparticles for treating dental hypersensitivity. Due to their superparamagnetic characteristics, these nanoparticles were susceptible to navigation inside the dental tubules via an external magnetic field. Polymer-coated maghemite nanoparticles exhibited a significant potential for reducing the permeability of dental tubules by occluding the open tubular area after a $120 \mathrm{~min}$ time. Moreover, these nanoparticles transferred other therapeutic agents inside the tubules [289]. Mei et al. developed HA disks with polydopamine-induced-PEG coating, finding anti-biofouling effect against a multi-species cariogenic biofilm on the root dentine surface [290]. Thoma etal. used PEG hydrogel as matrix in combination with $\mathrm{HA} /$ tricalcium phosphate for guided bone regeneration procedures. The presence of PEG led to a greater bone augmented area [291]. PPG is used in dental composites on the basis of its cytocompatibility. For example, Walters et al. affirmed that the use of composites containing PPG results in materials with excellent conversion, depth of cure, and mechanical properties, without increasing shrinkage. Moreover, they are more cytocompatible than those containing acrylates [292]. Münchow etal. synthesized an acidic monomer based on PPG phosphate methacrylate to constitute a self-etch adhesive system for the enamel [293]. PPG is also used to produce caries detecting dyes [294]. Similarly, poly(tetrahydrofuran)s are produced to decrease the cytotoxicity of epoxy-based dental resins. For example, Kostoryz et al. found significantly $(p<0.05)$ less cytotoxicity in this 
material, compared to acrylic resins. Then, addition of poly(tetrahydrofuran) in the formulation of epoxy-based resins contributes to the development of biocompatible dental composites [295]. Diniz etal. used Pluronic F-127 hydrogels as scaffold for encapsulation of dental-derived mesenchymal stem cells. They tested the osteogenic and adipogenic differentiation capacity of dental pulp stem cells in a thermoreversible Pluronic F127 hydrogel scaffold encapsulation system. After 2 weeks of differentiation in vitro, dental pulp stem cells exhibited high levels of mRNA expression for osteogenic and adipogenic gene markers. Furthermore, Pluronic F-127 presented a dense tubular and reticular network morphology, which contributed to its high permeability and solubility [296]. Similarly, Chen et al. used pluronic based tooth-binding micellar drug delivery platforms that effectively bind to tooth surfaces. Such micelles were able to bind HA and gradually release the encapsulated antimicrobial substance (farnesol). This system provided significant inhibition of Streptococcus mutans biofilm formation, legitimating its utilization for caries prevention and treatment [297]. In addition, Mogen et al. demonstrated that pluronic micelles themselves interact with the biofilm. These vectors induced alterations in biofilm architecture, presumably via interaction with the sucrose-dependent biofilm matrix, and are a viable treatment option for the prevention and treatment of pathogenic plaque biofilms [298]. The same anti-biofilm action of pluronic is found in toothpastes. In fact, Bali et al. showed the clinical efficacy of a dentifrice containing $0.2 \%$ triclosan and $0.5 \%$ pluronic in a calcium carbonate base for the reduction of supragingival plaque and gingivitis [299]. PEG diacrylate was used by Lu et al. to produce tunable hydrogel systems used as scaffold for dental pulp stem cells. In these devices, PEG diacrylate acts as cross-linker for PEG-fibrinogen hydrogels, permitting a encapsulation yield of dental pulp stem cells $>85 \%$ and modulating the odontogenic gene expression and mineralization through its cross-linking degree and matrix stiffness (the highest degree of mineralization is observed in the highest cross-linked hydrogel), finding application in regenerative endodontics [300]. PEG dimethacrylate found the same dental application, with the advantage to possess lower shrinkage [301]. Table 9 acts as summary of synthetic polyethers based devices used for dentistry. 
Table 9. Synthetic polyethers based dentistry devices

Device
PEG-like coatings on titanium dental implants
[288]

\subsubsection{Proteins and poly(amino acids)}

Proteins are high molecular weight polymers composed of amino acid monomers linked by amide bonds. They have three-dimensional folded structures and are one of the most common materials found in the human body. Proteins and amino acid-derived polymers are utilized in sutures, scaffolds, and drug delivery devices with prolonged degradation time. 
Collagen is the most abundant protein in the human body and is a major component of ligament, cartilage, tendon, skin, and bone. It also forms the structural network of other tissues like blood vessels. Collagen is composed of polypeptide strands bearing triamino acid blocks of Glycine-X-Y where X and Y are a number of different amino acids, mainly proline and hydroxyproline [302]. These polypeptides are formed into left-handed triple helix microfibrils that organize in different architectures to create collagen fibers with appropriate mechanical properties for their function. Collagen has various medical applications due to its biocompatibility, processability, mechanical strength, and enzymatic degradability by collagenases and metalloproteinases [303]. In fact, it is used as suture material in surgery [304], as depot delivery device in the local extended release of antibiotics [305], DNA [306], siRNA [307], and proteins [308] and as haemostatic sealant [309]. In tissue engineering, collagen sponges are widely diffused due to their ability to withstand high tensile loads (92.5 MPa ultimate tensile strength) [310]. Other applications of collagen relate to reconstructive skin surgery and tissue engineering scaffold for cartilage, tendon, and ligament [311]. In order to improve collagen's potential as a biomaterial it is combined with other degradable polymers [312] or is modified through cross-linking [313], association with bioactive molecules [314], and enzymatic pretreatment [315]. Moreover, composites of $\mathrm{HA}$ and collagen are utilized to mimic the composition of natural bone. For example, Collagraft ${ }^{\circledR}$ (Angiotech Pharmaceuticals) is a synthetic bone graft substitute composed of bovine type I collagen and $\mathrm{HA}$ /tricalcium phosphate granules which has been approved by the FDA and used clinically [316]. Collagen can be seen as a highly versatile dental material capable of being prepared into cross-linked compacted solids or into lattice-like gels. Collagen enhances wound healing following dental therapy by clot formation and stabilization, neovascularization, and epithelial cell rejuvenation [317]. Resorbable forms of collagen are used to dress oral wounds and for closure of graft and extraction sites. In fact, M. Chvapil et al. described the use of films made from hydrolyzed collagen as tissue adhesives for suture replacement due to their chemical resemblance to connective tissue and their tissue fluid-binding properties [318]. Collagen-based membranes are also used in periodontal and implant therapy as barriers to prevent epithelial migration and allow cells with regenerative capacity to repopulate the defect area creating a favorable environment for cellular development. Specifically, collagen bioresorbable membranes for guided tissue regeneration are chemotactic for periodontal ligament fibroblasts, act as a barrier for migrating epithelial cells, provide hemostasis, and serve as a fibrillar scaffold for early vascular and tissue ingrowth [319,320]. In addition, to significantly reduce antigenicity and biodegradation of the implant, cross-links are often introduced by either physical or chemical reagents (e.g., acetaldehyde, acrolein, formaldehyde, glyoxal, glutaraldehyde, and diphenylphosphoryl azide) $[321,322]$. 
Elastin is a highly elastic polymer, responsible for contraction of vascular and lung tissues, composed of cross-linked tropoelastin molecules. These molecules are produced intracellularly by smooth muscle cells and fibroblasts and are cross-linked outside the cells to become elastic [323]. Natural elastin is insoluble and elicits an immune response [324]. In order to overcome these limitations, tropoelastin is treated to undergo an irreversible temperature transition above $25^{\circ} \mathrm{C}$ to change its molecular organization from a disordered to an ordered state, obtaining favorable properties as injectable drug delivery system [325], and synthetic elastins are produced through controlled molding, coacervation, and cross-link [326]. Moreover, elastin-like polypeptides (ELPs) are available that are artificial polypeptides composed of pentapeptide repeats (VPGXG) similar to those found in elastin (X can be any amino acids except proline) characterized by biocompatibility, non-immunogenicity, and capability to be chemically synthesized [327] and are investigated as delivery vehicles for chemotherapeutics [328], antibiotics [329], and proteins [330]. The elastic behavior of ELPs makes them uniquely suited for the engineering of soft tissues [331]. In dentistry, elastin and elastin-like polypeptides are used in association with collagen. For example, Gurumurthy et al. improved the mechanical characteristics of collagen through the use of elastin-like polypeptides. The obtained scaffold allowed osteogenic differentiation of human adipose-derived stem cells cultures [332]. Osteoblast growth and expression on these composite scaffolds were evaluated also by Amruthwar et al. to validate the use of these devices on the treatment of alveolar bone loss [333].

Fibrin is a large cross-linked biopolymer composed of fibronectin, involved in the natural clotting process. The use of fibrin as a biomaterial results from its biocompatibility, biodegradability, injectability, and ability to enhance cell proliferation [334]. Currently, fibrin is investigated for use as drug delivery device [335] and cell carrier [336] and fibrin glues are commercially available (Evicel ${ }^{\circledR}$, Ethicon). In dentistry, the most recognized application of fibrin is in the platelet rich fibrin (PRF). PRF consists of an autologous leukocyte-plateletrich fibrin matrix with cytokines, platelets, and stem cells [337], that acts as biodegradable scaffold [338], favors the development of microvascularization, and is able to guide epithelial cell migration [339]. Also, PRF serves as vehicle in carrying cells involved in tissue regeneration and promotes sustained release of growth factors, stimulating the environment for wound healing [340]. Some studies demonstrate that PRF is a healing biomaterial with a great potential for bone and soft tissue regeneration, without inflammatory reactions, and can be used alone or in combination with bone grafts to promote hemostasis, bone growth, and maturation [341]. Moreover, it increases cell attachment and stimulates osteoblasts proliferation and differentiation [342]. A second generation of PRF was produced by Dohan et al. introducing a method that concentrated most platelets and leukocytes from a blood harvest into a single autologous fibrin biomaterial [343]. Finally, fibrin is 
used to create a dental scaffold material for tissue regeneration in the oral cavity. In fact, Galler et al. described a PEGylated fibrin hydrogel combined with stem cells derived from dental pulp or periodontal ligament able to allow the growth and differentiation of dental stem cells [344].

Natural poly(amino acids) are biodegradable, ionic polymers composed of repeated units of one type of amino acid, bonded by amide linkages. The two most commonly studied natural poly(amino acids) used as biomaterials are poly $(\gamma$-glutamic acid) and poly(L-lysine). Poly $(\gamma$-glutamic acid) $(\gamma \mathrm{PGA})$ is composed of both enantiomeric D- and L-glutamic acid units produced by several bacteria [345]. The reactive side carboxylate of $\gamma$ PGA allows the covalent attachment of other functional groups or drugs (e.g., chemotherapeutics) [346] and the formation of particle delivery systems for antibiotics, vaccines, DNA, and proteins [347]. Moreover, cross-linked $\gamma$ PGA hydrogels are used in soft tissue engineering alone or blended with other biodegradable polymers [348,349]. Similarly, bacterial poly(L-lysine) is currently investigated as a tissue engineering scaffold and drug delivery device with intrinsic antimicrobial [350] and antitumor activities [351]. However, its high positive charge limits its applications due to toxicity. Despite this, some uses derive from blending with other degradable polymers [352,353]. In dentistry, Kimetal. produced polymeric calcium phosphate cements incorporated with poly- $\gamma$-glutamic acid. The cross-link of $\gamma$ PGA confers mechanical strength to these calcium phosphate cements. Moreover, $\operatorname{poly}(\gamma$ glutamic acid) incorporation retards HA formation [354]. Poly(L-lysine) is widely used for the formation of coatings on dental materials. For example, Galli et al. treated with poly(L-lysine) a three-dimensional titanium-6aluminium-4-vanadium (Ti6Al4V) scaffold for orthopedic prosthesis and dental implants. Such modification improved the colonization ability of human mesenchymal stem cells (hMSCs) and dental pulp stem cells (hDPSCs), responsible for bone regeneration [355]. Similarly, Varoni et al. studied in vitro and in vivo effects of poly-L-lysine coating on titanium osseointegration. Such coating safely enhanced calcium deposition and implant early osseointegration in animals, suggesting promising evidence to optimize the surface properties of these dental implants [356]. Walters et al. investigated the antimicrobial properties of poly(L-lysine) in mono/tricalcium phosphates-HA composites. Highly soluble poly(L-lysine) enhanced mineral release and precipitation and had great potential in the prevention of recurrent caries and restoration failures [357].

Synthetic poly(amino acids) derive from the industrial polymerization of several homo- and copoly(amino acids). Synthetic poly(amino acids) functioning as promising biomaterials are poly(L-glutamic acid) and poly(aspartic acid). Poly(L-glutamic acid) (L-PGA) has the same primary structure of $\gamma \mathrm{PGA}$ but with the amide linkage made with the $\alpha$-carbon amine group instead of the $\gamma$-carbon amine group. The shorter distance between amide bonds makes L-PGA more flexible than $\gamma$ PGA. Moreover, L-PGA is easily 
produced and the development of new synthesis techniques allows the creation of unique architectures like dendrimers [358]. L-PGA is biocompatible, non-immunogenic, and highly susceptible to degradation by lysosomal enzymes [359]. It is used as a DNA delivery device [360] and for the construction of layer-by-layer film assembly with negatively charged polymers [361]. L-PGA is also combined with poly(L-lysine) or gelatin to create novel tissue engineering scaffolds [362]. Poly(aspartic acid) (PAA) is a highly water soluble ionic polymer with carboxylate content greater than PGA or L-PGA. PAA is degraded by lysosomal enzymes and it is often copolymerized with other polymers (e.g., PLA, PCL, and PEG) [363] to create micellar structures acting as smart delivery vehicles. Moreover, PAA can be easily converted to hydrogels with great biomedical applications [364]. In dentistry, BenkiraneJessel et al. patented a L-PGA based compound linked to Melanocortin peptides for use in endodontic regeneration and for the treatment of dental inflammatory diseases. Such device promotes human pulp fibroblast adhesion and cell proliferation and reduces the inflammatory state of lipopolysaccharide stimulated pulp fibroblasts observed in gram negative bacterial infections [365]. Osorio et al. developed a novel zinc-doped Portland-based resinous sealing cement linked with PAA with improved bonding efficacy and dentine remineralization ability. The polyaspartic acid application onto demineralized dentine inhibited mineral phase crystallization, enhancing the remineralization potential of the Portland microfillers at the resin-dentine bonded interface [366].

Table 10 recaps proteins and poly(amino acids) based devices used for dentistry. 
Table 10. Proteins and poly(amino acids) based dentistry devices

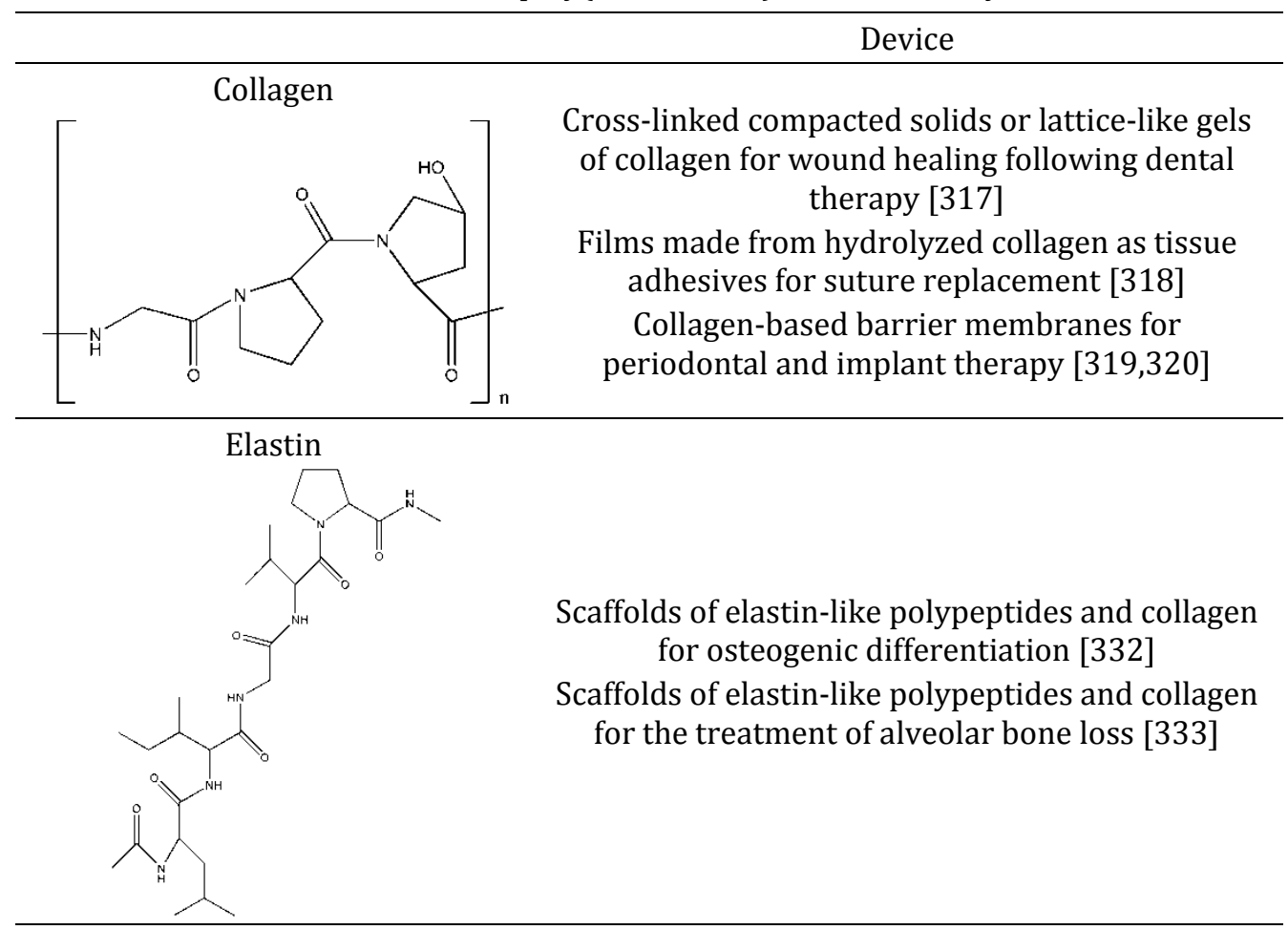

Fibrin<smiles>CNC(=O)CNC(=O)CN</smiles>

Platelet rich fibrin [337-340,342,343]

Fibrin based dental scaffold for tissue regeneration [344]

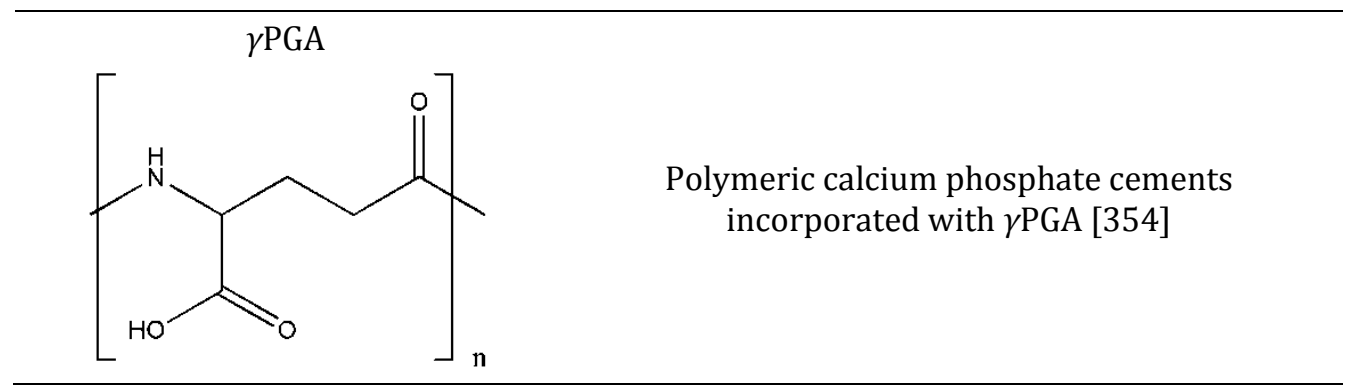


Table 10. (continued)

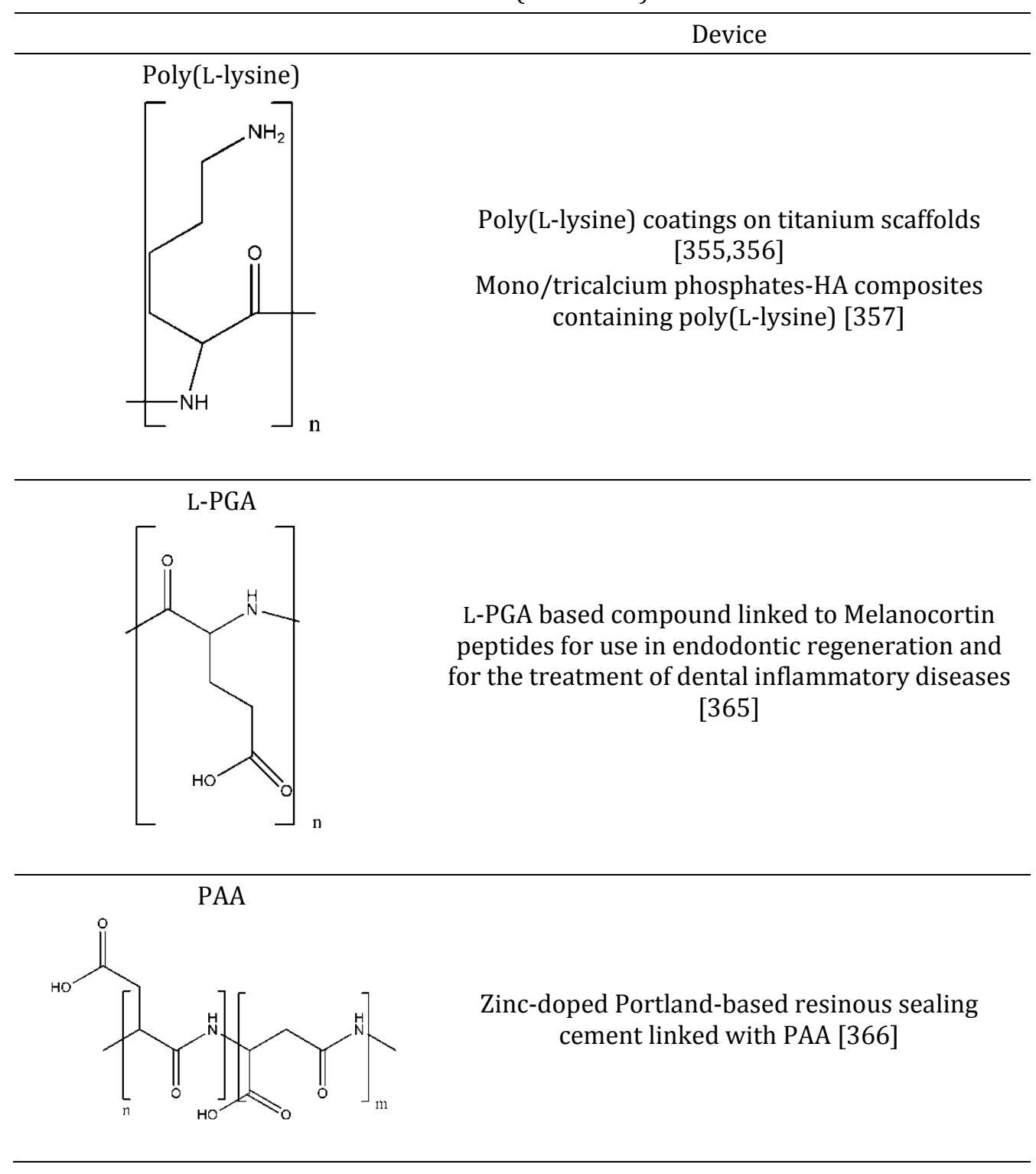




\subsubsection{Polysaccharides}

Polysaccharides are polymers composed of monosaccharide units linked through glycosidic linkages, a type of ether bond. Their biodegradability, processability, and bioactivity along with new biological functions identified for these materials and the array of available materials obtained by synthetic routes make polysaccharides very promising biomaterials.

Hyaluronic acid (HA) is a linear anionic polysaccharide, member of the glycosaminoglycan family, consisting of alternating units of $\mathrm{N}$-acetyl-Dglucosamine and glucuronic acid. HA is isolated from rooster combs and bovine vitreous humor. However, recent advances in biosynthetic techniques led to the microbiological production of sodium hyaluronate in Bacillus subtilis. In humans, such polymer is found in synovial fluid and vitreous humor and plays an important structural role in articular cartilage and skin. HA is water soluble and forms highly viscous solutions. It possesses scavenging free radicals properties, causes bacteriostasis, and assists in tissue repair [367]. However, HA homopolymer is too weak and fluid to create a supportive scaffold. To overcome this limitation, HA is cross-linked with ethyl esters, benzyl esters, or other biodegradable polymers to enhance the mechanical properties while retaining excellent biocompatibility [368,369]. Such HA hydrogels are extremely versatile and can be fabricated into sheets, membranes, sponges, tubes, fibers, and scaffolds for wound healing [370], regeneration of the trachea [371], cartilage [372], vasculature [373], and nerve tissues [374]. HA is also available in the form of nanoparticles to deliver chemotherapeutics and other drugs [375,376]. In the field of dentistry, hyaluronic acid shows anti-inflammatory and anti-bacterial effects in the treatment of periodontal diseases. Due to its tissue healing properties, it is used as an adjunct to mechanical therapy in the treatment of periodontitis and periodontal lesions. In fact, Pirnazar et al. suggested that HA, in the molecular weight range of $1,300 \mathrm{kDa}$, minimizes bacterial contamination of surgical wounds when used in guided tissue regeneration surgery [377]. Pilloni et al. evaluated the efficacy of an esterified form of HA gel on periodontal clinical parameters showing effects in reducing the gingival inflammation when used as an adjunct to mechanical home plaque control therapy [378]. El-Sayed et al. investigated the effect of local application of $0.8 \%$ hyaluronan gel in conjunction with periodontal surgery. Statistically significant differences were noted for clinical attachment level and gingival recession [379]. Gontiya et al. analyzed the clinical and histological outcomes of local subgingival application of $0.2 \% \mathrm{HA}$ gel as an adjunct to scaling and root planning in chronic periodontitis patients. The treated sites showed reduced inflammatory infiltrates [380]. Johannsen et al. evaluated the effect of local application of $0.8 \%$ hyaluronan gel in the process of scaling and root planning for the treatment of chronic periodontitis, finding a significant reduction in bleeding. Similarly, the use of $0.8 \%$ hyaluronan had major clinical benefits in terms of improved healing after non-surgical therapy [381]. Pistorius et al. evaluated 
the efficacy of topical application of HA for treatment of gingivitis and found that HA containing preparations are a useful adjunct in the anti-gingival therapy [382]. A commercialized gel formulation, Gengigel ${ }^{\circledR}$ (Ricerfarma S.r.l., Milano, Italy), contains high molecular weight $0.2 \%$ fractions of HA, for its effect in the treatment of plaque induced gingivitis as an adjunct [383]. Hyaluronan gel is also effective in controlling inflammation and gingival bleeding, as shown by a study of Mesa et al. that documented reduction in the depth of gingival pockets along with a significant decrease in epithelial and lymphocyte cell proliferation after the use of HA gel [384]. Similarly, $0.2 \%$ hyaluronan containing gel has a benefic effect on the treatment of plaque induced gingivitis due to the significant decrease in peroxidase and lysozyme activities [383]. In addition, De Arau'jo Nobre found that HA and chlorhexidine maintain a healthy perimplant complex in immediate function implants for complete rehabilitations in the edentulous mandible [385]. Ballini et al. noticed that autologous bone combined with esterified low molecular HA preparation accelerated new bone formation in the infrabone defects [386]. Vanden Bogaerde investigated the clinical efficacy of fibrous esterified HA for treating deep periodontal defects finding a sensible reduction of probing pocket depth [387,388].

Chondroitin sulfate (CHS) is a glycosaminoglycan similar to HA but with a sulfate group in at least one of its side groups. CHS is found in the wound healing matrix produced by fibroblasts [389]. CHS stimulates the metabolic response of cartilage [390], possesses anti-inflammatory properties [391], and connects cells to extracellular matrix components [392]. CHS is extensively studied as a hydrogel for wound dressings and cartilage tissue engineering, [393] alone or in association with other biodegradable polymers [394,395]. For dental applications, Sawatjui et al. fabricated a three-dimensional silk fibroin/gelatin-chondroitin sulfate-hyaluronic acid (SF-GCH) scaffold and showed that it promotes proliferation of mesenchymal stem cells by providing a supportive structure and the mimetic cartilage environment for chondrogenesis which enables cartilage regeneration [396].

Chitosan (CS) is the deacetylated derivative of chitin, a linear polysaccharide consisting of $\beta-1,4$ linked $N$-acetylglucosamine units that forms the exoskeletons of many arthropods. This polysaccharide is composed of randomly located units of D-glucosamine and $N$-acetylglucosamine and is degraded by the enzymes chitinase, chitosanase, lysozyme, cellulase, protease, lipase, and pepsin [397]. CS degradation rate depends on the degree of acetylation and crystallinity and can be regulated through the modification of side groups [398]. Moreover, CS is water absorptive, oxygen permeable, haemostatic, chemoattractive, and antibacterial and assists wound healing $[399,400]$. However, CS is mechanically weak and it is often cross-linked or combined with other degradable polymers to form films, membranes, sponges, particles, fibers, and gels used for bandages [401,402], delivery devices [403-406], and tissue engineering scaffolds for regenerative applications [407- 
409]. Uses of CS in dentistry are related to its antibacterial and wound healing actions. In fact, the polycationic nature of CS, with active amino and hydroxyl functional groups, permits good adhesion to salivary pellicles and creates positive charges that interact with microbial cell surfaces provoking loss of microbial cell barrier function [410]. Sano et al. demonstrated the effect of increased hydrophobicity of salivary pellicles after CS adsorption and the obtained reduced adhesion of Streptococcus sobrinus to saliva coated HA disks [411]. They also found that low molecular weight CS inhibits the initial adhesion of oral bacteria to human tooth surfaces at a level comparable to that of a $50 \mathrm{ppm}$ chlorhexidine solution [412]. Similar results were found by Busscher et al. that evaluated the effects of a CS on bacterial adhesion and growth on CS treated pellicles founding a reduction in bacterial adhesion and bacterial death upon contact [413]. Researchers have also explored the applications of CS in dentifrices and dental adhesives. In fact, Mohire et al. developed CS based polyherbal toothpastes (with eugenol, Pterocarpus marsupium aqueous extract, Stevia rebaudiana aqueous extract, and Glycyrrhiza glabra aqueous extract) with enhanced performance in oral care as CS inhibits the growth of Streptococcus mutans and Porphyromonas gingivalis, microorganisms responsible for caries and gingivitis [414]. Elsaka evaluated the antibacterial activity and bond strength of dental adhesives modified with various concentrations of CS. Adhesives with the lower concentrations of CS were more effective against $S$. mutans. Moreover, greater concentration of CS has negative effects on microtensile bond strength, degree of conversion, and $\mathrm{pH}$ [415]. CS is also used in implant dentistry as surface modifier. Electrodeposition of CS in combination with calcium phosphate on the titanium implants significantly improved the biocompatibility with no adverse effects on the other properties of implants [416]. Recently, more attention has been paid to the use of CS to stabilize dentin collagen. Such biopolymers are incorporated into the collagen matrix or cross-linked with collagen fibrils to improve the biological and mechanical properties of collagen constructs [417]. Finally, CS is widely utilized as scaffold material because of its good biocompatibility and degradability via naturally occurring enzymes [418-419].

Alginate is a high biocompatible linear copolymer composed of $\beta$-Dmannuronic acid and $\alpha$-L-glucuronic acid linked by a 1-4 glycosidic bond commonly extracted from the cell wall of brown algae. Alginate forms spontaneous gels when exposed to divalent cations (e.g., $\mathrm{Ca}^{2+}$ ), used as drug delivery devices, wound healing dressings, and tissue engineering scaffolds [420]. For example, alginate based hydrogels are produced for the delivery of chondrocytes [421], osteoblasts [422], myoblasts [423], fibroblasts, and keratinocytes [424]. In addition, alginate is also available as composite systems in which it is associated with polyesthers [425], polyethers [426], collagen [427], and CS [428] to effectively deliver drugs or proteins [429] and to form scaffolds composed of films, sponges, fibers, gels, and freeze casted porous networks used in regenerative engineering [430,431]. Cellular adhesion on 
these devices is improved by side group modification of alginate with the RGD (Arg-Gly-Asp) peptides [432]. In dentistry, Ishikawa et al. introduced sodium alginate $(0-2.0 \mathrm{wt} \%)$ into the liquid phase of calcium phosphate cement to produce a non-decay type fast-setting cement. The mechanical strength of this composite increased rapidly with the addition of sodium alginate up to $0.8 \mathrm{wt} \%$ and such device results particularly in being useful in orthodontics and oral and maxillofacial surgery where the cement is exposed to blood [433]. The same authors introduced sodium alginate also in HA putty behaving as self-curing. This HA is easier to use than the simple non-decay type fast-setting cement in the filling of bone defects [434]. However, the most diffused use of alginate in dentistry is as impression material thanks to its biocompatibility and elastic behavior [435,436]. Table 11 summarizes polysaccharides based devices used for dentistry.

Table 11. Polysaccharides based dentistry devices

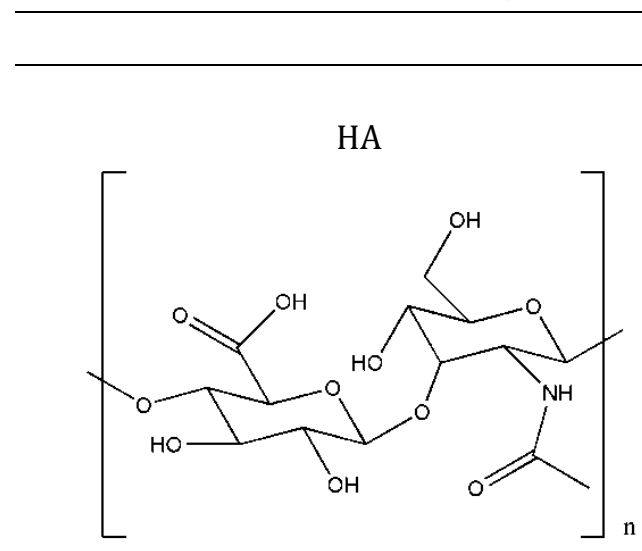

Device

Adjunct to mechanical therapy of periodontitis and periodontal lesions

[377]

Esterified form of HA gel for gingival inflammation [378]

Hyaluronan gel [379-384] Gengige ${ }^{\circledR}[383]$

HA and chlorhexidine complexes [385]

Autologous bone combined with esterified low molecular HA preparation [386]

Fibrous esterified HA $[387,388]$

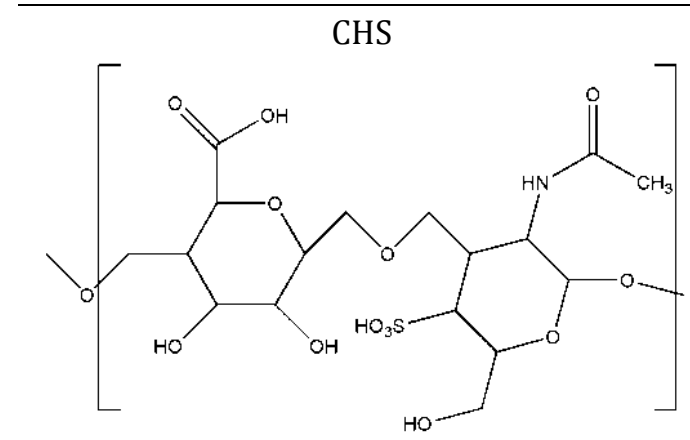

Three-dimensional silk fibroin/gelatinchondroitin sulfate-hyaluronic acid scaffolds [396] 
Table 11. (continued)

Device

CS

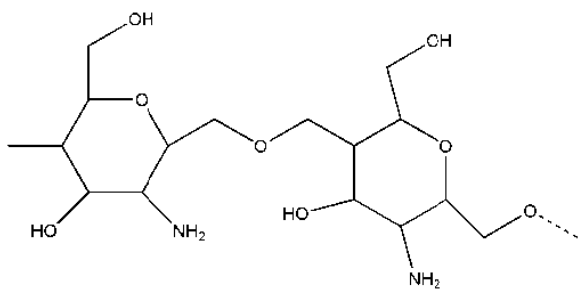

Alginate

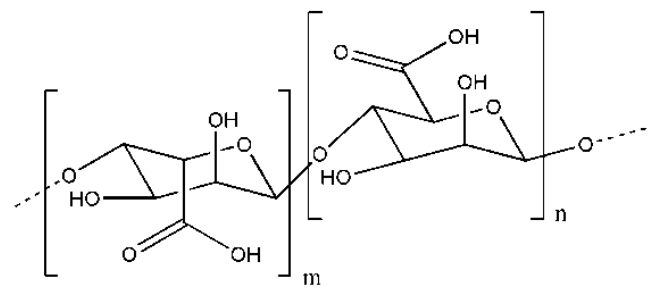

CS based polyherbal toothpastes [414]

CS based dental adhesives [415]

Electrodeposition of CS in combination with calcium phosphate on titanium implants [416]

CS-collagen constructs [417]

CS scaffolds [418,419]

Sodium alginate-calcium phosphate cements [433]

Self-curing sodium alginate-HA putty [434]

Alginate based impression materials $[435,436]$

\subsection{CONCLUDING REMARKS}

Modern dental practice would have been impossible without the application of various natural or artificial degradable polymers. These materials can be utilized as eternal prosthesis or for temporary use thanks to their ability to break down and be absorbed by the body. Biodegradable polymers offer great potential for controlled drug delivery, wound management (e.g., adhesives and sutures), dental restorations, and tissue engineering. The application of biodegradable polymers started several decades ago, and since then it has been the focus of much research. This is because the requirements are quite complex: the polymer must be biocompatible, not to evoke an inflammatory response, and must have suitable mechanical and processing characteristics. Furthermore, the degradation products cannot be harmful and must be readily resorbed or excreted. Since the requirements are variable, there is no ideal polymer for use in dentistry. In addition, the current interest of research relates to the design of biomaterial scaffolds for tissue regeneration. These biodegradable tissue-engineered constructs are based on stem cells and are produced to release bioactive stimuli able to guide tissue regeneration. Then, the further development of the applications of biodegradable polymers for dental tissue engineering and regeneration requires deeper knowledge about the products of degradation of polymers along with information on basic tissue biology and molecular mechanisms of tissue turnover at different periods of human life and in different diseases. 


\section{ACKNOWLEDGMENT}

This work was supported by Progetto PON-“Ricerca e Competitività 20072013"-PON01_01802: "Sviluppo di molecole capaci di modulare vie metaboliche intracellulari redox-sensibili per la prevenzione e la cura di patologie infettive, tumorali, neurodegenerative e loro delivery mediante piattaforme nano tecnologiche," PON01_02512: "Ricerca e sviluppo di bioregolatori attivi sui meccanismi epigenetici dei processi infiammatori nelle malattie croniche e degenerative," PON03_00106: "Materiali Avanzati per la Ricerca ed il comparto Agroalimentare, Laboratorio Pubblico-Privato, MAReA," and PRIN 2012 (prot. 201288JKYY): "Nanotecnologie per variare i programmi di sviluppo osseo nella parete vasale per la prevenzione e trattamento delle patologie associate alla calcificazione ectopica arteriosa."

\section{REFERENCES}

1. $\quad$ E. Piskin. J. Biomater. Sci. Polym. Ed. 6 (1995) 775-795.

2. J.K. Abraham, J. Domb, D. Wiseman, Handbook of Biodegradable Polymers. CRC press, Boca Raton, USA, 1998.

3. D.F. Williams. Biomaterials 30 (2009) 5897-5909.

4. B.D. Ulery, L.S. Nair, C.T. Laurencin. J. Polym. Sci. Part B: Polym. Phys. 49 (2011) 832-864.

5. K.J.L. Burg, S.W. Shalaby, Absorbable and Biodegradable Polymers. CRC Press, Boca Raton, USA, 2003.

6. A.W. Lloyd. Med. Device. Technol. 13 (2002) 18-21.

7. J.D. Bryers, C.M. Giachelli, B.D. Ratner. Biotechnol. Bioeng. 109 (2012) 1898-1911.

8. B.D. Ulery, L.S. Nair, C.T. Laurencin. J. Polym. Sci. Part B: Polym. Phys. 49 (2011) 832-864.

9. E. Battistella, E. Varoni, A. Cochis, B. Palazzo,L. Rimondini. J. Appl. Biomater. Biomech. 9 (2011) 223-231.

10. M.J. Tyas, K.J. Anusavice, J.E. Frencken, G.J. Mount. Int. Dent. J. 50 (2000) 1-12.

11. N. Takahashi, B. Nyvad. J. Dent. Res. 90 (2011) 294-303.

12. D.D.B. Antonio Nanci. Periodontology 200040 (2006) 18.

13. D.E. Frank, W.G. Carter. J. Cell. Sci. 117 (2004) 1351-1363.

14. H.E. Schroeder, M.A. Listgarten. Periodontol. 200013 (1997) 91-120.

15. T. Karring, N.P. Lang, H. Loe. J. Periodontal. Res. 10 (1975) 1-11.

16. D.D. Bosshardt, H.E. Schroeder. Acta Anat. (Basel) 150 (1994) 253-266.

17. D.D. Bosshardt, H.E. Schroeder. The Anat. Record 245 (1996) 267-292.

18. D.D. Bosshardt. J. Dent. Res. 84 (2005) 390-406.

19. T. Karring, S. Nyman, J. Gottlow, L. Laurell. Periodontol. 20001 (1993) 26-35.

20. M.C. Groeneveld, T. Van den Bos, V. Everts, W. Beertsen. J. Periodontal. Res. 31 (1996) 73-79.

21. L. Häkkinen, O. Oksala, T. Salo, F. Rahemtulla, H. Larjava. J. Histochem. Cytochem. 41 (1993) 1689-1699.

22. D.S. Xiaolin Zhang, J. Becker, P. Reichart, H.R. Gelderblom. J. Histochem. Cytochem. 41 (1993) 7. 
23. J.L. Saffar, J.J. Lasfargues, M. Cherruau. Periodontol. 200013 (1997) 76-90.

24. M. Shahmoradi, L.E. Bertassoni, H.M. Elfallah, M. Swain, Fundamental Structure and Properties of Enamel, Dentin and Cementum. In Advances in Calcium Phosphate Biomaterials, Ben-Nissan, B., Ed. Springer Berlin Heidelberg: Berlin, Heidelberg, 2014; pp. 511-547.

25. R. d'Aquino, A. De Rosa, G. Laino, F. Caruso, L. Guida, R. Rullo, V. Checchi, L. Laino, V. Tirino, G. Papaccio. J. Exp. Zool. B Mol. Dev. Evol. 312b (2009) 408415.

26. R.C. Page, S. Offenbacher, H.E. Schroeder, G.J. Seymour, K.S. Kornman. Periodontol. 200014 (1997) 216-248.

27. R.I. Garcia, M.M. Henshaw, E.A. Krall. Periodontol. 200025 (2001) 21-36.

28. J. Kim,S. Amar. Odontol. Soc. Nippon Dent. Univ. 94 (2006) 10-21.

29. S.S. Socransky, A.D. Haffajee, M.A. Cugini, C. Smith, R.L. Kent Jr. J. Clin. Periodontol. 25 (1998) 134-144.

30. S.R. Goldring. Calcif. Tissue Int. 73 (2003) 97-100.

31. D. Grcevic, V. Katavic, I.K. Lukic, N. Kovacic, J.A. Lorenzo, A. Marusic. Croat. Med. J. 42 (2001) 384-392.

32. J.A.N. Potempa, A. Banbula, J.I.M. Travis. Periodontol. 200024 (2000) 153192.

33. W.J. Loesche, Microbiology of Dental Decay and Periodontal Disease. In Medical Microbiology. $4^{\text {th }}$ edition., S, B., Ed. University of Texas Medical Branch at Galveston: Galveston (TX), 1996.

34. B.S. van Loghum. Tandartspraktijk 36 (2015) 33-35.

35. G.J. Christensen. J. Am. Dent. Assoc. 136 (2005) 1711-1713.

36. T. Fusayama. Oper. Dent. 4 (1979) 63-70.

37. G. Sammartino, G. Pantaleo, P. Nuzzolo, M. Amato, F. Riccitiello. J. Oral. Implantol. 42 (2016) 176-179.

38. J.M. Laudenbach, Z. Simon. Med. Clin. North Am. 98 (2014) 1239-1260.

39. F. Zarone, S. Rengo, F. Riccitiello. Attual. Dent. 7 (1991) 16-18.

40. A. Della Bona, J.R. Kelly. J. Am. Dent. Assoc. 139 (2008) 8s-13s.

41. M. Rathore, A. Singh, V.A. Pant. Toxicol. Int. 19 (2012) 81-88.

42. C.A. Price. Australian Prosthodontic J. 8 (1994) 47-54.

43. R.L. Bowen. J. Am. Dent. Assoc. 66 (1963) 57-64.

44. C.K. Yiu, E.L. Pashley, N. Hiraishi, N.M. King, C. Goracci, M. Ferrari, R.M. Carvalho, D.H. Pashley, F.R. Tay. Biomaterials 26 (2005) 6863-6872.

45. B. Zimmerli, M. Strub, F. Jeger, O. Stadler, A. Lussi. Schweiz Monatsschr. Zahnmed. 120 (2010) 972-986.

46. E. Habib, R. Wang, Y. Wang, M. Zhu, X.X. Zhu. ACS Biomater. Sci. Eng. 2 (2016) 1-11.

47. A. Wiegand, W. Buchalla, T. Attin. Dent. Mater. 23 (2007) 343-362.

48. A. Calarco, A. Di Salle, L. Tammaro, I. De Luca, S. Mucerino, O. Petillo, F. Riccitiello, V. Vittoria, G. Peluso. J. Dent. Res. 94 (2015) 1099-1105.

49. L. Tammaro, V. Vittoria, A. Calarco, O. Petillo, F. Riccitiello, G. Peluso. J. Dent. 42 (2014) 60-67.

50. M.S. Baig, G.J.P. Fleming. J. Dent. 43 (2015) 897-912.

51. M. Khoroushi, F. Keshani. Dent. Res. J. 10 (2013) 411-420.

52. F.A.P. Rizzante, R.S. Cunali, J.F.S. Bombonatti, G.M. Correr, C.C. Gonzaga, A.Y. FuruseI. RSBO (Online) 12 (2015) 79-87.

53. D. Dionysopoulos, E. Koliniotou-Koumpia, M. Helvatzoglou-Antoniades, N. 
Kotsanos. Dent. Mater. J. 32 (2013) 296-304.

54. R. Consiglio, S. Rengo, D. Liguoro, F. Riccitiello, S. Formisano, G. Palumbo,B. Di Jeso. Arch. Oral Biol. 43 (1998) 65-71.

55. S.B. Mitra, J.D. Oxman, A. Falsafi, T.T. Ton. Am. J. Dent. 24 (2011) 372-378.

56. K.S. Dhull, B. Nandlal. J. Indian Soc. Pedod. Prev. Dent. 27 (2009) 27-32.

57. A.J. Smith, N. Cassidy, H. Perry, C. Begue-Kirn, J.V. Ruch, H. Lesot. Int. J. Dev. Biol. 39 (1995) 273-280.

58. A.J. Smith, R.S. Tobias, C.G. Plant, R.M. Browne, H. Lesot, J.V. Ruch. J. Biol. Buccale 18 (1990) 123-129.

59. V. Mironov, R.P. Visconti, R.R. Markwald. Exp. Opin. Biol. Therapy 4 (2004) 773-781.

60. L.L. Hench, J.M. Polak. Science 295 (2002) 1014-1017.

61. A. Atala, D.J. Irvine, M. Moses, S. Shaunak. Mater. Res. Soc. 35 (2010) 10.1557.

62. J.D. Kretlow, A.G. Mikos. AIChE J. 54 (2008) 3048-3067.

63. C. Mason, P. Dunnill. Regen. Med. 3 (2008) 1-5.

64. M. Vert. Int. J. Artif. Organs 34 (2011) 76-83.

65. A. Lendlein, A.T. Neffe, B.F. Pierce, J. Vienken. Int. J. Artif. Organs 34 (2011) 71-75.

66. M. Pudlas, S. Koch, C. Bolwien, H. Walles. Int. J. Artif. Organs 33 (2010) 228-237.

67. A. Rainer, M. Centola, C. Spadaccio, G. Gherardi, J.A. Genovese, S. Licoccia,M. Trombetta. Int. J. Artif. Organs 33 (2010) 76-85.

68. L. Altomare, M. Riehle, N. Gadegaard, M.C. Tanzi, S. Fare. Int. J. Artif. Organs 33 (2010) 535-543.

69. A.L. Sisson, D. Steinhilber, T. Rossow, P. Welker, K. Licha, R. Haag. Angew Chem. Int. Ed. Engl. 48 (2009) 7540-7545.

70. G. Serino, W. Rao, G. Iezzi, A. Piattelli. Clin. Oral Implants Res. 19 (2008) 26-31.

71. R.J. Narayan, Philosop. Trans. Royal Soc. of London A: Math. Phys. Eng. Sci. 368 (2010) 1831-1837.

72. L. Moller, A. Krause, J. Dahlmann, I. Gruh, A. Kirschning, G. Drager. Int. J. Artif. Organs 34 (2011) 93-102.

73. W.L. Murphy, T.C. McDevitt, A.J. Engler. Nat. Mater. 13 (2014) 547-557.

74. F. von Burkersroda, L. Schedl, A. Gopferich. Biomaterials 23 (2002) 4221-4231.

75. J.A. Tamada, R. Langer. Proc. Natl. Acad. Sci. U S A 90 (1993) 552-556.

76. A.S. Determan, B.G. Trewyn, V.S. Lin, M. Nilsen-Hamilton, B. Narasimhan. J. Control. Release 100 (2004) 97-109.

77. X. Wen, P.A. Tresco. Biomaterials 27 (2006) 3800-3809.

78. A. Göpferich. Macromolecules 30 (1997) 2598-2604.

79. O. Coulembier, P. Degée, J.L. Hedrick, P. Dubois. Prog. Polym. Sci. 31 (2006) 723-747.

80. P.B. Maurus,C.C. Kaeding. Oper. Tech. Sports Med. 12 158-160.

81. P. Gunatillake, R. Mayadunne, R. Adhikari. Biotechnol. Annu. Rev. 12 (2006) 301-347.

82. K. Ceonzo, A. Gaynor, L. Shaffer, K. Kojima, C.A. Vacanti, G.L. Stahl. Tissue Eng. 12 (2006) 301-308.

83. A.R. Katz, R.J. Turner. Surg. Gynecol. Obstet. 131 (1970) 701-716.

84. T.M. Reed. J. Foot Ankle Surg. 38 (1999) 14-23. 
85. S. Knecht, C. Erggelet, M. Endres, M. Sittinger, C. Kaps, E. Stussi. J. Biomed. Mater. Res. B Appl. Biomater. 83 (2007) 50-57.

86. H.K. Pihlajamaki, S.T. Salminen, O. Tynninen, O.M. Bostman, O. Laitinen. Calcif. Tissue Int. 87 (2010) 90-98.

87. L. Wang, N.H. Dormer, L.F. Bonewald, M.S. Detamore. Tissue Eng. Part A 16 (2010) 1937-1948.

88. D.D. Frisbie, Y. Lu, C.E. Kawcak, E.F. DiCarlo, F. Binette, C.W. Mcllwraith. Am. J. Sports Med. 37 (2009) 71s-80s.

89. N. Mahmoudifar, P.M. Doran. Biomaterials 31 (2010) 3858-3867.

90. L. Xu, D. Cao, W. Liu, G. Zhou, W.J. Zhang, Y. Cao. Biomaterials 31 (2010) 3894-3902.

91. A. Sayasneh, H. Johnson. J. Obstet. Gynaecol. 30 (2010) 721-724.

92. E. Aysan, H. Bektas, F. Ersoz, S. Sari, A. Kaygusuz. Int. J. Clin. Exp. Med. 3 (2010) 341-346.

93. T. Dai, Z. Jiang, S. Li, G. Zhou, J.D. Kretlow, W. Cao, W. Liu, Y. Cao. J. Biotechnol. 150 (2010) 182-189.

94. A. Abbushi, M. Endres, M. Cabraja, S.N. Kroppenstedt, U.W. Thomale, M. Sittinger, A.A. Hegewald, L. Morawietz, A.J. Lemke, V.G. Bansemer, C. Kaps, C. Woiciechowsky. Spine (Phila Pa 1976) 33 (2008) 1527-1532.

95. T. Ohara, T. Itaya, K. Usami, Y. Ando, H. Sakurai, M.J. Honda, M. Ueda, H. Kagami. J. Biomed.Mater. Res. Part A 94A (2010) 800-805

96. F. Baumchen, R. Smeets, D. Koch, H.G. Graber. Oral Surg. Oral Med. Oral Pathol. Oral Radiol. Endod. 108 (2009) 505-513.

97. J.C. Middleton, A. J. Tipton. Biomaterials 21 (2000) 2335-2346.

98. M.R. Nobile, P. Cerruti, M. Malinconico, R. Pantani. J. Appl. Polym. Sci. 132 (2015).

99. R. Suuronen, T. Pohjonen, J. Hietanen, C. Lindqvist. J. Oral Maxillofac. Surg. 56 (1998) 604-614.

100. J.S. Loo, C.P. Ooi, F.Y. Boey. Biomaterials 26 (2005) 1359-1367.

101. S.C. Loo, H.T. Tan, C.P. Ooi, Y C. Boey. Acta Biomater. 2 (2006) 287-296.

102. I.K. Shim, M.R. Jung, K.H. Kim, Y.J. Seol, Y.J. Park, W.H. Park, S.J. Lee. J. Biomed. Mater. Res. B Appl. Biomater. 95 (2010) 150-160.

103. Y.Z. Cai, L.L. Wang, H.X. Cai, Y.Y. Qi, X.H. Zou, H.W. Ouyang. J. Biomed. Mater. Res. A 95 (2010) 49-57.

104. Y. Tanaka, H. Yamaoka, S. Nishizawa, S. Nagata, T. Ogasawara, Y. Asawa, Y. Fujihara, T. Takato, K. Hoshi. Biomaterials 31 (2010) 4506-4516.

105. A. Inui, T. Kokubu, T. Makino, I. Nagura, N. Toyokawa, R. Sakata, M. Kotera, T. Nishino, H. Fujioka, M. Kurosaka. Int. Orthop. 34 (2010) 1327-1332.

106. H.B. Wang, M.E. Mullins, J.M. Cregg, C.W. McCarthy, R.J. Gilbert. Acta Biomater. 6 (2010) 2970-2978.

107. S. Francois, N. Chakfe, B. Durand,G. Laroche. Acta Biomater. 5 (2009) 2418-2428.

108. L. Tang, C. Zhao, Y. Xiong, A. Wang. Int. Orthop. 34 (2010) 755-759.

109. E. Carletti, T. Endogan, N. Hasirci, V. Hasirci, D. Maniglio, A. Motta, C. Migliaresi. J. Tissue Eng. Regen Med. 5 (2011) 569-577.

110. N.Y. Yu, A. Schindeler, L. Peacock, K. Mikulec, P.A. Baldock, A.J. Ruys, D.G. Little. Eur. Cell Mater. 20 (2010) 431-441.

111. L. Calandrelli, A. Calarco, P. Laurienzo, M. Malinconico, O. Petillo, G. Peluso. Biomacromolecules 9 (2008) 1527-1534. 
112. D.D. Hile, S.A. Doherty, D.J. Trantolo. J. Biomed. Mater. Res.

Part B: Appl.Biomater. 71B (2004) 201-205.

113. H. Peltoniemi, N. Ashammakhi, R. Kontio, T. Waris, A. Salo, C. Lindqvist, K. Grätz, R. Suuronen. Oral Surg. Oral Med. Oral Pathol. Oral Radiol. Endodontol. 94 (2002) 5-14.

114. J. Conn Jr., R. Oyasu, M. Welsh, J.M. Beal. Am. J. Surg. 128 (1974) 19-23.

115. P. Clavert, J.J. Warner. Arthroscopy 21 (2005) 200-203.

116. J. Liu, Z. Qiu, S. Wang, L. Zhou, S. Zhang. Biomed. Mater. 5 (2010) 065002.

117. T. Betancourt, B. Brown, L. Brannon-Peppas. Nanomedicine (Lond) 2 (2007) 219-232.

118. M. Ye, S. Kim, K. Park. J. Control. Release 146 (2010) 241-260.

119. W. Jiang, S.P. Schwendeman. Mol. Pharm. 5 (2008) 808-817.

120. S. Jhunjhunwala, G. Raimondi, A.W. Thomson, S.R. Little. J. Control. Release 133 (2009) 191-197.

121. E. Vega, F. Gamisans, M.L. Garcia, A. Chauvet, F. Lacoulonche, M.A. Egea. J. Pharm. Sci. 97 (2008) 5306-5317.

122. S. Eperon, L. Bossy-Nobs, I.K. Petropoulos, R. Gurny, Y. Guex-Crosier. Int. J. Pharm. 352 (2008) 240-247.

123. N. Murata, Y. Takashima, K. Toyoshima, M. Yamamoto, H. Okada. J Control. Release 126 (2008) 246-254.

124. Y. Patil, J. Panyam. Int. J. Pharm. 367 (2009) 195-203.

125. R.L. Simpson, F.E. Wiria, A.A. Amis, C.K. Chua, K.F. Leong, U.N. Hansen, M. Chandrasekaran, M.W. Lee. J. Biomed. Mater. Res. B Appl. Biomater. 84 (2008) 17-25.

126. E. Jabbarzadeh, T. Starnes, Y.M. Khan, T. Jiang, A.J. Wirtel, M. Deng, Q. Lv, L.S. Nair, S.B. Doty, C.T. Laurencin. Proc. Natl. Acad. Sci. U S A 105 (2008) 11099-11104.

127. J.P. Spalazzi, M.C. Vyner, M.T. Jacobs, K.L. Moffat, H.H. Lu. Clin. Orthop. Relat. Res. 466 (2008) 1938-1948.

128. J. Xie, X. Li, J. Lipner, C.N. Manning, A.G. Schwartz, S. Thomopoulos, Y. Xia. Nanoscale 2 (2010) 923-926.

129. C. Stoll, T. John, M. Endres, C. Rosen, C. Kaps, B. Kohl, M. Sittinger, W. Ertel, G. Schulze-Tanzil. J. Orthop. Res. 28 (2010) 1170-1177.

130. K.A. Blackwood, R. McKean, I. Canton, C.O. Freeman, K.L. Franklin, D. Cole, I. Brook, P. Farthing, S. Rimmer, J.W. Haycock, A.J. Ryan, S. MacNeil. Biomaterials 29 (2008) 3091-3104.

131. F. Wen, S. Chang, Y.C. Toh, T. Arooz, L. Zhuo, S.H. Teoh, H. Yu. J. Biomed. Mater. Res. B Appl. Biomater. 87 (2008) 154-162.

132. H.E. Olson, G.E. Rooney, L. Gross, J.J. Nesbitt, K.E. Galvin, A. Knight, B. Chen, M.J. Yaszemski, A.J. Windebank. Tissue Eng. Part A 15 (2009) 1797-1805.

133. K.S. Hassan. Oral Surg. Oral Med. Oral Pathol. Oral Radiol. Endodontol. 108 (2009) e19-e25.

134. A.A. Jones, D. Buser, R. Schenk, J. Wozney, D.L. Cochran. J. Periodontol. 77 (2006) 1184-1193.

135. Z. Wu, C. Liu, G. Zang, H. Sun. Int. J. Oral Maxillofac. Surg. 37 (2008) 170-176.

136. B.P. Levin. Compend. Contin. Educ. Dent. 34 (2013) 178-186.

137. Y.-S. Liu, M.-E. Ou, H. Liu, M. Gu, L.-W. Lv, C. Fan, T. Chen, X.-H. Zhao, C.-Y. Jin, X. Zhang, Y. Ding, Y.-S. Zhou. Biomaterials 35 (2014) 4489-4498.

138. N. Kawakatsu, S. Oda, A. Kinoshita, S. Kikuchi, H. Tsuchioka, T. Akizuki, C. 
Hayashi, S. Kokubo, I. Ishikawa, Y. Izumi. J. Oral Rehabilit. 35 (2008) 647-655.

139. E.C. Carlo Reis, A.P.B. Borges, M.V.F. Araújo, V.C. Mendes, L. Guan, J.E. Davies. Biomaterials 32 (2011) 9244-9253.

140. T. Hayakawa, C. Mochizuki, H. Hara, F. Yang, H. Shen, S. Wang, M. Sato. J. Mater. Sci.: Mater. Med. 21 (2010) 251-258.

141. T. Yoshida, H. Miyaji, K. Otani, K. Inoue, K. Nakane, H. Nishimura, A. Ibara, A. Shimada, K. Ogawa, E. Nishida, T. Sugaya, L. Sun, B. Fugetsu, M. Kawanami, J. Periodontal. Res. 50 (2015) 265-273.

142. D.H. Kwon, F.C. Bisch, R.W. Herold, C. Pompe, P. Bastone, N.A. Rodriguez, C. Susin, U.M.E. Wikesjö. J.Clin.Periodontol. 37 (2010) 667-674.

143. E.H.C. van Manen, W. Zhang, X.F. Walboomers, B. Vazquez, F. Yang, W. Ji, N. Yu, D.J. Spear, J.A. Jansen, P.C. Yelick. Odontol. 102 (2014) 14-21.

144. Y. Shirakata, T. Nakamura, Y. Shinohara, K. Taniyama, K. Sakoda, T. Yoshimoto, K. Noguchi. J. Mater. Sci.: Mater. Med. 25 (2014) 899-908.

145. M.K. Marei, M.M. Saad, A.M. El-Ashwah, R.M. El-Backly, M.A. Al-Khodary. J. Oral Implantol. 35 (2009) 106-129.

146. R.M. El-Backly, A.G. Massoud, A.M. El-Badry, R.A. Sherif, M.K. Marei. Australian Endodontic J. 34 (2008) 52-67.

147. L. Zheng, F. Yang, H. Shen, X. Hu, C. Mochizuki, M. Sato, S. Wang, Y. Zhang. Biomaterials 32 (2011) 7053-7059.

148. D. Akita, M. Morokuma, Y. Saito, K. Yamanaka, Y. Akiyama, M. Sato, T. Mashimo, T. Toriumi, Y. Arai, T. Kaneko, N. Tsukimura, K. Isokawa, T. Ishigami, M.J. Honda. Biomed. Res. (Japan) 35 (2014) 91-103.

149. F.F.O. Sousa, A. Luzardo-Álvarez, A. Pérez-Estévéz, R. Seoane-Prado, J. BlancoMéndez. Biomed. Mater. 5 (2010) 055008.

150. H. Zhao, B. Wu, H. Wu, L. Su, J. Pang, T. Yang, Y. Liu. Biotechnol. Lett. 28 (2006) 1299-1304.

151. R. Smeets, F. Gerhards, J. Stein, R.M. Pereira Paz, S. Vogt, C. Pautke, J. Weitz, A. Kolk. J. Biomed. Mater. Res. Part A 96 (2011) 177-185.

152. D.Z. Liu, W.P. Chen, C.P. Lee, S.L. Wu, Y.C. Wang, T.W. Chung. J. Microencapsulation 21 (2004) 643-652.

153. R.C. Mundargi, S. Srirangarajan, S.A. Agnihotri, S.A. Patil, S. Ravindra, S.B. Setty, T.M. Aminabhavi. J. Control. Release 119 (2007) 59-68.

154. I.C. Yue, J. Poff, M.A.E. Cortés, R.D. Sinisterra, C.B. Faris, P. Hildgen, R. Langer, V.P. Shastri. Biomaterials 25 (2004) 3743-3750.

155. J. Tariq, R.Md. Akhlaquer, M.M. Aamir, A.K. Panda, T. Sushama, I. Zeenat. Curr. Drug Deliv. 9 (2012) 515-526.

156. P.-C. Chang, A.S. Dovban, L.P. Lim, L.Y. Chong, M.Y. Kuo, C.-H. Wang. Biomaterials 34 (2013) 9990-9997.

157. L. Hong, Y. Krishnamachari, D. Seabold, V. Joshi, G. Schneider, A.K. Salem. Tissue Eng. Part C: Meth. 17 (2010) 319-325.

158. Y. Naito, T. Terukina, S. Galli, Y. Kozai, S. Vandeweghe, T. Tagami, T. Ozeki, T. Ichikawa, P.G. Coelho, R. Jimbo. Int. J. Pharm. 461 (2014) 157-162.

159. Y. Yonamine, T. Matsuyama, T. Sonomura, H. Takeuchi, Y. Furuichi, M. Uemura, Y. Izumi, K. Noguchi. Oral Surg. Oral Med. Oral Pathol. Oral Radiol. 109 (2010) 225-231.

160. J.S. Son, Y.-A. Choi, E.-K. Park, T.-Y. Kwon, K.-H. Kim, K.-B. Lee. J. Part B: Appl. Biomater. 101B (2013) 247-257. 
161. F. Wang, Y.-l. Song, C.-X. Li, D.-H. Li, H.-P. Zhang, A.-J. Ma, X.-Q. Xi, N. Zhang, B.-G. Wang, Y. Wang, W. Zhou. Eur. J. Pharm. 640 (2010) 226-232.

162. G.-K. Zou, Y.-L. Song, W. Zhou, M. Yu, L.-H. Liang, D.-C. Sun, D.-H. Li, Z.-X. Deng, W.-Z. Zhu. Oral Surg. Oral Med. Oral Pathol. Oral Radiol. 114 (2012) 284-289.

163. S. Samdancioglu, S. Calis, M. Sumnu, A. Atilla Hincal. Drug. Dev. Ind. Pharm. 32 (2006) 473-481.

164. T. Masuzaki, Y. Ayukawa, Y. Moriyama, Y. Jinno, I. Atsuta, Y. Ogino, K. Koyano. Biomaterials 31 (2010) 3327-3334.

165. Y. Han, Q. Zeng, L.E.D. Wang, H. He, H. Liu. J. Oral Maxillofac. Surg. 70 (2012) 2299-2308.

166. H. Abe, Y. Doi. Int. J. Biol. Macromol. 25 (1999) 185-192.

167. C. Zhijiang, W. Zhihong. J. Mater. Sci. 42 (2007) 5886-5890.

168. T. Laeger, C.C. Metges, B. Kuhla. Appetite 54 (2010) 450-455.

169. C.W. Pouton, S. Akhtar. Adv. Drug Deliv. Rev. 18 (1996) 133-162.

170. Y. Ke, Y.J. Wang, L. Ren, Q. C. Zhao, W. Huang. Acta Biomater. 6 (2010) 1329-1336.

171. J. Liu, B. Zhao, Y. Zhang, Y. Lin, P. Hu, C. Ye. J. Biomed. Mater. Res. A 94 (2010) 603-610.

172. Y. Ji, X.T. Li, G.Q. Chen. Biomaterials 29 (2008) 3807-3814.

173. T. Ahmed, H. Marcal, M. Lawless, N.S. Wanandy, A. Chiu, L.J. Foster. Biomacromolecules 11 (2010) 2707-2715.

174. C. Yang, D. Plackett, D. Needham, H.M. Burt. Pharm. Res. 26 (2009) 1644-1656.

175. X. Li, K.L. Liu, M. Wang, S.Y. Wong, W.C. Tjiu, C.B. He, S.H. Goh, J. Li. Acta Biomater. 5 (2009) 2002-2012.

176. M. Auriemma, A. Piscitelli, R. Pasquino, P. Cerruti, M. Malinconico, N. Grizzuti. Eur. Polym. J. 63 (2015) 123-131.

177. P. Persico, V. Ambrogi, A. Baroni, G. Santagata, C. Carfagna, M. Malinconico, P. Cerruti. Int. J. Biol. Macromol. 51 (2012) 1151-1158.

178. H. Ueda, Y. Tabata. Adv. Drug Deliv. Rev. 55 (2003) 501-518.

179. P. Galgut, R. Pitrola, I. Waite, C. Doyle, R. Smith. J. Clin. Periodontol. 18 (1991) 581-586.

180. T.S. Leenstra, J.C. Maltha, A.M. Kuijpers-Jagtman. J.Mater. Sci.: Mater. Med. 6 (1995) 445-450.

181. A. Patlolla, G. Collins, T.L. Arinzeh. Acta Biomater. 6 (2010) 90-101.

182. M.R. Nobile, G. Lucia, M. Santella, M. Malinconico, P. Cerruti, R. Pantani. AIP Conf. Proc. 1695 (2015) 020058.

183. F. Danhier, B. Vroman, N. Lecouturier, N. Crokart, V. Pourcelle, H. Freichels, C. Jerome, J. Marchand-Brynaert, O. Feron, V. Preat. J. Control. Release 140 (2009) 166-173.

184. S. Chung, N.P. Ingle, G.A. Montero, S.H. Kim, M.W. King. Acta Biomater. 6 (2010) 1958-1967.

185. M. Stanzione, O. Petillo, A. Calarco, E. Valarezo, M. Napoli, P. Longo, F. Riccitiello, V. Vittoria, G. Peluso, J Appl Biomater Funct Mater 11 (2013) e61-e70.

186. V. Guarino, L. Ambrosio. Acta Biomater. 4 (2008) 1778-1787.

187. Y. Zuo, F. Yang, J.G. Wolke, Y. Li, J.A. Jansen. Acta Biomater. 6 (2010) 1238-1247.

188. R. De Santis, A. Gloria, T. Russo, U. D'Amora, V. D'Antò, F. Bollino, M. Catauro, F. 
Mollica, S. Rengo, L. Ambrosio. Polym. Composites 34 (2013) 1413-1417.

189. J.W. Hayami, D.C. Surrao, S.D. Waldman, B.G. Amsden. J. Biomed. Mater. Res. A 92 (2010) 1407-1420.

190. C. Vaquette, C. Kahn, C. Frochot, C. Nouvel, J.L. Six, N. De Isla, L.H. Luo, J. Cooper-White, R. Rahouadj, X. Wang. J. Biomed. Mater. Res. A 94 (2010) 1270-1282.

191. W.J. Li, H. Chiang, T.F. Kuo, H.S. Lee, C.C. Jiang, R.S. Tuan. J. Tissue Eng. Regen. Med. 3 (2009) 1-10.

192. D.R. Nisbet, A.E. Rodda, M.K. Horne, J.S. Forsythe, D.I. Finkelstein. Biomaterials 30 (2009) 4573-4580.

193. S. Heydarkhan-Hagvall, K. Schenke-Layland, A.P. Dhanasopon, F. Rofail, H. Smith, B.M. Wu, R. Shemin, R.E. Beygui, W.R. MacLellan. Biomaterials 29 (2008) 2907-2914.

194. M.-H. Huang, A.-H. Chou, S.-P. Lien, H.-W. Chen, C.-Y. Huang, W.-W. Chen, P. Chong, S.-J. Liu, C.-H. Leng. J. Biomed. Mater. Res. Part B:

Appl. Biomater. 90B (2009) 832-841.

195. J.J. Kim, W.J. Bae, J.M. Kim, J.J. Kim, E.J. Lee, H.W. Kim, E.C. Kim. J. Biomater. Appl. 28 (2014) 1069-1078.

196. B. Chuenjitkuntaworn, T. Osathanon, N. Nowwarote, P. Supaphol, P. Pavasant. J. Biomed. Mater. Res. Part A 104 (2016) 264-271.

197. S. He, M.D. Timmer, M.J. Yaszemski, A.W. Yasko, P.S. Engel, A.G. Mikos, Polymer 42 (2001) 1251-1260.

198. E.M. Christenson, W. Soofi, J.L. Holm, N.R. Cameron, A.G. Mikos. Biomacromolecules 8 (2007) 3806-3814.

199. M.C. Hacker, A. Haesslein, H. Ueda, W.J. Foster, C.A. Garcia, D.M. Ammon, R.N. Borazjani, J.F. Kunzler, J.C. Salamone, A.G. Mikos. J. Biomed. Mater. Res. A 88 (2009) 976-989.

200. M. Jayabalan, K.T. Shalumon, M.K. Mitha, K. Ganesan, M. Epple. Acta Biomater. 6 (2010) 763-775.

201. A.S. Mistry, Q.P. Pham, C. Schouten, T. Yeh, E.M. Christenson, A.G. Mikos, J.A. Jansen. J. Biomed. Mater. Res. A 92 (2010) 451-462.

202. D.L. Alge, J. Bennet, T. Treasure, S. Voytik-Harbin, W.S. Goebel, T.-M. G. Chu. J. Biomed. Mater. Res.Part A 100 (2012) 1792-1802.

203. S. Shahabi, Y. Rezaei, F. Moztarzadeh, F. Najafi, In vitro degradation and bioactivity of PPF/bioactive glass sintered microsphere scaffolds for bone tissue engineering. In Science and Engineering of Composite Materials, 2016; Vol. 23, p. 245.

204. M. Agueros, V. Zabaleta, S. Espuelas, M.A. Campanero, J.M. Irache. J. Control. Release 145 (2010) 2-8.

205. M.Y. Krasko, J. Golenser, A. Nyska, M. Nyska, Y.S. Brin, A.J. Domb. J. Control. Release 117 (2007) 90-96.

206. I. Tamayo, J.M. Irache, C. Mansilla, J. Ochoa-Reparaz, J.J. Lasarte, C. Gamazo. Clin. Vaccine Immunol. 17 (2010) 1356-1362.

207. L.K. Petersen, C.K. Sackett, B. Narasimhan. Acta Biomater. 6 (2010) 38733881.

208. C. Manoharan, J. Singh. J. Pharm. Sci. 98 (2009) 4237-4250.

209. J.P. Jain, S. Modi, N. Kumar. J. Biomed. Mater. Res. A 84 (2008) 740-752.

210. A.A. Weiner, D.M. Shuck, J.R. Bush, V.P. Shastri. Biomaterials 28 (2007) 5259-5270. 
211. A.A. Weiner, E.A. Bock, M.E. Gipson, V.P. Shastri. Biomaterials 29 (2008) 2400-2407.

212. K.S. Anseth, V.R. Shastri, R. Langer. Nat. Biotech. 17 (1999) 156-159.

213. H. Hasturk, A. Kantarci, M. Ghattas, S.J. Dangaria, R. Abdallah, E.F. Morgan, T. G. Diekwisch, A. Ashman, T. Van Dyke. J. Periodontol. 85 (2014) 1230-1239.

214. K.E. Uhrich, Polyanhydrides with biologically active degradation products. Google Patents: 2002.

215. K.E. Uhrich, Polyanhydride linkers for production of drug polymers and drug polymer compositions produced thereby. Google Patents: 2010.

216. M.L. Johnson, R. T. S. U. o. N. J.-N. B. G. S.-N. Brunswick, Polyanhydride Blends as Drug Delivery Matrices to Control Biofilms, Bone, and Nerve Regeneration. Rutgers The State University of New Jersey - New Brunswick, 2008.

217. M.J. Heffernan, N. Murthy. Bioconjug. Chem. 16 (2005) 1340-1342.

218. S. Lee, S.C. Yang, M.J. Heffernan, W.R. Taylor, N. Murthy. Bioconjug. Chem. 18 (2007) 4-7.

219. G. Seshadri, J.C. Sy, M. Brown, S. Dikalov, S.C. Yang, N. Murthy, M.E. Davis. Biomaterials 31 (2010) 1372-1379.

220. S.M. Standley, Y.J. Kwon, N. Murthy, J. Kunisawa, N. Shastri, S.J. Guillaudeu, L. Lau, J.M. Frechet. Bioconjug. Chem. 15 (2004) 1281-1288.

221. M.W. Betz, P.C. Modi, J.F. Caccamese, D.P. Coletti, J.J. Sauk, J.P. Fisher. J. Biomed. Mater. Res. A 86 (2008) 662-670.

222. J.S. Fitton, E.H. Davies, J.A. Howlett, G.J. Pearson. Clin. Mater. 17 (1994) 125-129.

223. Y. Savion, A. Sharon-Buller, Y. Kalisker, N. Kalisker, M. Sela. Refuat Hapeh Vehashinayim (1993) 18 (2001) 30-31.

224. T. Jiao, T. Chang, A.A. Caputo. Australian Dent. J. 54 (2009) 31-37.

225. M. Qi, X. Li, Y. Yang, S. Zhou. Eur. J. Pharm. Biopharm. 70 (2008) 445-452.

226. D.N. Nguyen, S.S. Raghavan, L.M. Tashima, E.C. Lin, S.J. Fredette, R.S. Langer, C. Wang. Biomaterials 29 (2008) 2783-2793.

227. M.B. Polak, F. Valamanesh, O. Felt, A. Torriglia, J.-C. Jeanny, J.-L. Bourges, P. Rat, A. Thomas-Doyle, D. BenEzra, R. Gurny, F. Behar-Cohen. Invest. Ophthalmol. Visual Sci. 49 (2008) 2993-3003.

228. M. Ekholm, P. Helander, J. Hietanen, C. Lindqvist, A. Salo, M. Kellomaki, R. Suuronen. Int. J. Oral Maxillofac. Surg. 35 (2006) 631-635.

229. K.V. Roskos, B.K. Fritzinger, S.S. Rao, G.C. Armitage, J. Heller. Biomaterials 16 (1995) 313-317.

230. K. Schwach-Abdellaoui, P.J. Loup, N. Vivien-Castioni, A. Mombelli, P. Baehni, J. Barr, J. Heller, R. Gurny. AAPS PharmSci. 4 (2002) 14-20

231. L. Erdmann, B. Macedo, K.E. Uhrich. Biomaterials 21 (2000) 2507-2512

232. Z. Zhang, R. Kuijer, S.K. Bulstra, D.W. Grijpma, J. Feijen. Biomaterials 27 (2006) 1741-1748.

233. A.P. Pego, M.J. Van Luyn, L.A. Brouwer, P.B. van Wachem, A.A. Poot, D.W. Grijpma, J. Feijen. J. Biomed. Mater. Res. A 67 (2003) 1044-1054

234. W.J. Habraken, Z. Zhang, J.G. Wolke, D.W. Grijpma, A.G. Mikos, J. Feijen, J.A. Jansen. Biomaterials 29 (2008) 2464-2476

235. O.S. Kluin, H.C. van der Mei, H.J. Busscher, D. Neut. Biomaterials 30 (2009)

236. E. Bat, J. Feijen, D.W. Grijpma. Biomacromolecules 11 (2010) 2692-2699

237. W. Chen, F. Meng, F. Li, S.J. Ji, Z. Zhong. Biomacromolecules 10 (2009) 1727-1735 
238. B.G. Amsden, L. Timbart, D. Marecak, R. Chapanian, M.Y. Tse, S.C. Pang. J. Control. Release 145 (2010) 109-115.

239. A. Welle, M. Kroger, M. Doring, K. Niederer, E. Pindel, I.S. Chronakis. Biomaterials 28 (2007) 2211-2219.

240. F. Suriano, R. Pratt, J.P. Tan, N. Wiradharma, A. Nelson, Y.Y. Yang, P. Dubois, J. L. Hedrick. Biomaterials 31 (2010) 2637-2645.

241. T. Briggs, M.D. Treiser, P.F. Holmes, J. Kohn, P.V. Moghe, T.L. Arinzeh. J. Biomed. Mater. Res. A 91 (2009) 975-984.

242. P.A. Johnson, A. Luk, A. Demtchouk, H. Patel, H.J. Sung, M.D. Treiser, S. Gordonov, L. Sheihet, D. Bolikal, J. Kohn, P.V. Moghe. J. Biomed. Mater. Res. A 93 (2010) 505-514.

243. M.C. Costache, H. Qu, P. Ducheyne, D.I. Devore. Biomaterials 31 (2010) 6336-6343.

244. J.C. Feldner, N.K. Sarkar, J.J. Sheridan, D.M. Lancaster. Am. J. Orthodont. Dentofac. Orthoped. 106 (1994) 265-272.

245. R.G. Alkire, M.D. Bagby, M.A. Gladwin, H. Kim. Dent. Mater. 13 (1997) 2-6.

246. G.J. Pronych, E.J. Sutow, O. Sykora. J. Oral Rehab.. 30 (2003) 1157-1161.

247. J. Jancar, A.T. Dibenedetto. J. Mater. Sci.: Mater. Med. 4 (1993) 555-561

248. J. Jancar, A.T. Dibenedetto, A.J. Goldberg. J. Mater. Sci.: Mater. Med. 4 (1993) 562-568.

249. S.A. Guelcher. Tissue Eng. Part B Rev. 14 (2008) 3-17.

250. I. Yilgor, E. Yilgor. Polym. Rev. 47 (2007) 487-510.

251. T. Asai, M.H. Lee, C. Arrecubieta, M.P. von Bayern, C.A. Cespedes, H.M. Baron, M. Cadeiras, T. Sakaguchi, C.C. Marboe, Y. Naka, M.C. Deng, F.D. Lowy. J. Thorac. Cardiovasc. Surg. 133 (2007) 1147-1153.

252. P. Uttayarat, A. Perets, M. Li, P. Pimton, S.J. Stachelek, I. Alferiev, R.J. Composto, R.J. Levy, P.I. Lelkes. Acta Biomater. 6 (2010) 4229-4237.

253. S. Backman, G. Bjorling, U.B. Johansson, M. Lysdahl, A. Markstrom, U. Schedin, R.E. Aune, C. Frostell, S. Karlsson. Laryngoscope 119 (2009) 657-664.

254. M. Lavorgna, P. Cerruti, G. Casula, S. Iannace, J.F. Harper. Adv. Polym. Technol. 26 (2007) 132-145.

255. J.H. Kim, K.B. Kim, W.C. Kim, J.H. Kim, H.Y. Kim. Korean J. Orthod. 44 (2014) 69-76.

256. G. Mampieri, A. Giancotti. Prog. Orthod. 14 (2013) 40-40.

257. S.-Y. Kim, S.-H. Lee, S.-K. Cho, C.-M. Jeong, Y.-C. Jeon, M.-J. Yun, J.-B. Huh. J. Adv. Prosthodont. 6 (2014) 1-7.

258. R.L. Boyd, R.J. Miller, V. Vlaskalic. J. Clin. Orthodontics 34 (2000).

259. J.-H. Lee, S.-A. Cho. J. Prosthetic Dent. 114 (2) (2015) 305-306.

260. M.H. Selten, F.I. Broekema, J. Zuidema, W. van Oeveren, R.R. Bos. Ned. Tijdschr. Tandheelkd. 120 (2013) 378-382.

261. H. Alter, A. Fookson. J. Adhesion 3 (1971) 35-55.

262. C.T. Laurencin, H.J. Koh, T.X. Neenan, H.R. Allcock, R. Langer. J. Biomed. Mater. Res. 21 (1987) 1231-1246.

263. S. Lakshmi, D.S. Katti, C.T. Laurencin. Adv. Drug Deliv. Rev. 55 (2003) 467-482.

264. A. Singh, N.R. Krogman, S. Sethuraman, L.S. Nair, J.L. Sturgeon, P.W. Brown, C. T. Laurencin, H.R. Allcock. Biomacromolecules 7 (2006) 914-918.

265. Y.J. Jun, J.H. Kim, S.J. Choi, H.J. Lee, M.J. Jun, Y.S. Sohn. Bioorg. Med. Chem. Lett. 17 (2007) 2975-2978.

266. J.X. Zhang, X.J. Li, L.Y. Qiu, X.H. Li, M.Q. Yan, J. Yi, K.J. Zhu. J. Control. Release 
116 (2006) 322-329.

267. A.K. Andrianov, A. Marin, D.P. DeCollibus. Pharm. Res. 28 (2011) 58-65.

268. C. Chun, S.M. Lee, C.W. Kim, K Y. Hong, S.Y. Kim, H.K. Yang, S.C. Song. Biomaterials 30 (2009) 4752-4762.

269. N. Nicoli Aldini, M. Fini, M. Rocca, G. Giavaresi, R. Giardino. Int. Orthopaedics 24 (2000) 121-125.

270. M.T. Conconi, S. Lora, S. Baiguera, E. Boscolo, M. Folin, R. Scienza, P. Rebuffat, P.P. Parnigotto, G.G. Nussdorfer. J. Biomed. Mater. Res. A 71 (2004) 669-674.

271. S.P. Nukavarapu, S.G. Kumbar, J.L. Brown, N.R. Krogman, A.L. Weikel, M.D. Hindenlang, L.S. Nair, H.R. Allcock, C.T. Laurencin. Biomacromolecules 9 (2008) 1818-1825.

272. R. Razavi, Z. Khan, C.B. Haeberle, D. Beam. J. Prosthodont. 2 (1993) 224-227.

273. M. Ohashi, M. Anzai, Dental cavity filling composite material. Google Patents: 1986.

274. T. Ohta, A. Tani, K. Kimbara, F. Kawai. Appl. Microbiol. Biotechnol. 68 (2005) 639-646.

275. P.L. Alexander, V. Kabanov, S. Vinogradov, V. Alakhov. Adv. Drug Deliv. Rev. 54 (2002) 11.

276. B. Foster, T. Cosgrove, B. Hammouda. Langmuir 25 (2009) 6760-6766.

277. W. Zhang, Y. Shi, Y. Chen, S. Yu, J. Hao, J. Luo, X. Sha, X. Fang. Eur. J. Pharm. Biopharm. 75 (2010) 341-353.

278. A. Aka-Any-Grah, K. Bouchemal, A. Koffi, F. Agnely, M. Zhang, M. Djabourov, G. Ponchel. Eur. J. Pharm. Biopharm. 76 (2010) 296-303.

279. A.V. Vashi, E. Keramidaris, K.M. Abberton, W.A. Morrison, J.L. Wilson, A.J. O'Connor, J.J. Cooper-White, E.W. Thompson. Biomaterials 29 (2008) 573-579.

280. J.A. Beamish, J. Zhu, K. Kottke-Marchant, R.E. Marchant. J. Biomed. Mater. Res. A 92 (2010) 441-450.

281. P.M. Pfister, M. Wendlandt, P. Neuenschwander, U.W. Suter. Biomaterials 28 (2007) 567-575.

282. J.A. Diramio, W.S. Kisaalita, G.F. Majetich, J.M. Shimkus. Biotechnol. Prog. 21 (2005) 1281-1288.

283. A.C. Jimenez-Vergara, V. Guiza-Arguello, S. Becerra-Bayona, D.J. Munoz-Pinto, R.E. McMahon, A. Morales, L. Cubero-Ponce, M.S. Hahn. Ann. Biomed. Eng. 38 (2010) 2885-2895.

284. A. Papadopoulos, D.A. Bichara, X. Zhao, S. Ibusuki, M.A. Randolph, K.S. Anseth, M.J. Yaremchuk. Tissue Eng. Part A 17 (2011) 161-169.

285. Y.F. Poon, Y. Cao, Y. Zhu, Z.M. Judeh, M.B. Chan-Park. Biomacromolecules 10 (2009) 2043-2052.

286. G. Ma, X. Zhang, J. Han, G. Song, J. Nie. Int. J. Biol. Macromol. 45 (2009) 499-503.

287. X. Zhang, H. He, C. Yen, W. Ho, L.J. Lee. Biomaterials 29 (2008) 4253-4259.

288. J. Buxadera-Palomero, C. Canal, S. Torrent-Camarero, B. Garrido, F. Javier Gil, D. Rodriguez. Biointerphases 10 (2015) 029505.

289. A. Dabbagh, N.H. Abu Kasim, M.M. Bakri, H. Wakily, C. Ramasindarum, B.J.J. Abdullah. Mater. Lett. 121 (2014) 89-92.

290. M. Mei, Q.-L. Li, C. Chu. Materials 9 (2016) 414.

291. D.S. Thoma, U.-W. Jung, J.-Y. Park, S.P. Bienz, J. Hüsler, R.E. Jung. Clin. Oral Implants Res. 5 (2016) 1600-1651.

292. N.J. Walters, W. Xia, V. Salih, P.F. Ashley, A.M. Young. Dent. Mater. 32 (2016) 264-277. 
293. E.A. Münchow, A.F. da Silva, G.d.S. Lima, T. Wulff, M. Barbosa, F.A. Ogliari, E. Piva. J. Dent. 43 (2015) 94-102.

294. Y. Hosoya, T. Taguchi, S. Arita, F.R. Tay. J. Dent. 36 (2008) 1041-1047.

295. E.L. Kostoryz, P.Y. Tong, C.C. Chappelow, J.D. Eick, A.G. Glaros, D.M. Yourtee. Dent. Mater. 15 (1999) 363-373.

296. I.M.A. Diniz, C. Chen, X. Xu, S. Ansari, H.H. Zadeh, M.M. Marques, S. Shi, A. Moshaverinia, J. Mater. Sci. Mater. Med. 26 (2015) 153.

297. F. Chen, X.-M. Liu, K.C. Rice, X. Li, F. Yu, R.A. Reinhardt, K.W. Bayles, D. Wang. Antimicrob. Agents Chemother. 53 (2009) 4898-4902.

298. A.B. Mogen, F. Chen, S.-J. Ahn, R.A. Burne, D. Wang, K.C. Rice. PLoS ONE 10 (2015) e0133886.

299. R. Bali, R. Kohli, K. Rustogi, A. Volpe. J. Indian Assoc. Public Health Dent. 3 (2003) 1-5.

300. Q. Lu, M. Pandya, A.J. Rufaihah, V. Rosa, H.J. Tong, D. Seliktar, W.S. Toh. Stem Cells Int. 2015 (2015) 525367.

301. M. Atai, M. Ahmadi, S. Babanzadeh, D.C. Watts. Dent. Mater. 23 (2007) 1030-1041.

302. J.A. Ramshaw, N.K. Shah, B. Brodsky. J. Struct. Biol. 122 (1998) 86-91.

303. S.M. Krane. Amino Acids 35 (2008) 703-710.

304. N. Yilmaz, S. Inal, M. Muglali, T. Guvenc, B. Bas. Medicina Oral Patología Oral y Cirugia Bucal (2010) e526-e530.

305. O. Friberg, L.G. Dahlin, J. Kallman, E. Kihlstrom, B. Soderquist, R. Svedjeholm. Interact. Cardiovasc. Thorac. Surg. 9 (2009) 454-458.

306. C. Holladay, M. Keeney, U. Greiser, M. Murphy, T. O'Brien, A. Pandit. J. Control. Release 136 (2009) 220-225.

307. R. Vinas-Castells, C. Holladay, A. di Luca, V.M. Diaz, A. Pandit. Bioconjug. Chem. 20 (2009) 2262-2269.

308. H. Maehara, S. Sotome, T. Yoshii, I. Torigoe, Y. Kawasaki, Y. Sugata, M. Yuasa, M. Hirano, N. Mochizuki, M. Kikuchi, K. Shinomiya, A. Okawa. J. Orthop. Res. 28 (2010) 677-686.

309. S.H. Baik, J.H. Kim, H.H. Cho, S.N. Park, Y.S. Kim, H. Suh. J. Surg. Res. 164 (2010) e221-228.

310. A. Sionkowska, J. Skopinska-Wisniewska, M. Gawron, J. Kozlowska, A. Planecka. Int. J. Biol. Macromol. 47 (2010) 570-577.

311. L.M. Robayo, V.J. Moulin, P. Tremblay, R. Cloutier, J. Lamontagne, A.M. Larkin, S. Chabaud, F. Simon, N. Islam, F. Goulet. Wound Repair. Regen. 19 (2011) 38-48.

312. L. Wang, J.P. Stegemann. Biomaterials 31 (2010) 3976-3985.

313. L.P. Yan, Y.J. Wang, L. Ren, G. Wu, S.G. Caridade, J.B. Fan, L.Y. Wang, P.H. Ji, J. M. Oliveira, J.T. Oliveira, J.F. Mano, R.L. Reis. J. Biomed. Mater. Res. A 95 (2010) 465-475.

314. C.L. Casper, W. Yang, M.C. Farach-Carson, J.F. Rabolt. Biomacromolecules 8 (2007) 1116-1123.

315. G. Ciardelli, P. Gentile, V. Chiono, M. Mattioli-Belmonte, G. Vozzi, N. Barbani, P. Giusti. J. Biomed. Mater. Res. A 92 (2010) 137-151.

316. J.S. Grimes, T.J. Bocklage, J.D. Pitcher. Orthopedics 29 (2006) 145-148.

317. U.M. Wikesjo, R.E. Nilveus, K.A. Selvig. J. Periodontol. 63 (1992) 158-165.

318. M. Chvapil, L. Kronenthal, W. Van Winkle Jr. Int. Rev. Connect. Tissue Res. 6 (1973) 1-61. 
319. D.N. Tatakis, A. Promsudthi, U.M.E. Wikesjö. Periodontolo. 200019 (1999) 59-73.

320. S. Pitaru, H. Tal, M. Soldinger, M. Noff. J. Periodontal. Res. 24 (1989) 247-253.

321. N.J. Vardaxis, J.M. Ruijgrok, D.C. Rietveld, E.M. Marres, M.E. Boon. J. Biomed. Mater. Res. 28 (1994) 1013-1025.

322. H. Petite, I. Rault, A. Huc, P. Menasche, D. Herbage. J. Biomed. Mater. Res. 24 (1990) 179-187.

323. C.R. Kothapalli, A. Ramamurthi,. Acta Biomater. 6 (2010) 170-178.

324. S.M. Mithieux, J.E. Rasko, A.S. Weiss. Biomaterials 25 (2004) 4921-4927.

325. D. Kaufmann, R. Weberskirch. Macromol. Biosci. 6 (2006) 952-958.

326. Y. Tu, S. G. Wise, A.S. Weiss. Micron. 41 (2010) 268-272.

327. D.M. Floss, K. Schallau, S. Rose-John, U. Conrad, J. Scheller. Trends Biotechnol. 28 (2010) 37-45.

328. I. Massodi, E. Thomas, D. Raucher. Molecules 14 (2009) 1999-2015.

329. S.B. Adams, M.F. Shamji, D.L. Nettles, P. Hwang, L.A. Setton. J. Biomed. Mater. Res. Part B: Appl. Biomater. 90B (2009) 67-74.

330. P.C. Bessa, R. Machado, S. Nurnberger, D. Dopler, A. Banerjee, A.M. Cunha, J.C. Rodriguez-Cabello, H. Redl, M. van Griensven, R.L. Reis, M. Casal. J. Control. Release 142 (2010) 312-318.

331. D.L. Nettles, A. Chilkoti, L.A. Setton. Adv. Drug Deliv. Rev. 62 (2010) 1479-1485.

332. B. Gurumurthy, P.C. Bierdeman, A.V. Janorkar. Dent. Mater. 10 (2016) 1270-1280.

333. S.S. Amruthwar, A.V. Janorkar. Dent. Mater. 29 (2013) 211-220.

334. F.M. Shaikh, A. Callanan, E.G. Kavanagh, P.E. Burke, P.A. Grace, T.M. McGloughlin. Cells Tissues Organs 188 (2008) 333-346.

335. H.S. Yang, S.H. Bhang, J.W. Hwang, D.I. Kim, B.S. Kim. Tissue Eng. Part A 16 (2010) 2113-2119.

336. M. Peura, A. Siltanen, I. Saarinen, A. Soots, J. Bizik, J. Vuola, A. Harjula, E. Kankuri. J. Biomed. Mater. Res. A 95 (2010) 658-664.

337. J. Choukroun, A. Diss, A. Simonpieri, M.O. Girard, C. Schoeffler, S.L. Dohan, A.J. Dohan, J. Mouhyi, D.M. Dohan. Oral. Surg. Oral. Med. Oral. Pathol. Oral. Radiol. Endod. 101(2006) e56-e60.

338. Q. Li, S. Pan, S.J. Dangaria, G. Gopinathan, A. Kolokythas, S. Chu, Y. Geng, Y. Zhou, X. Luan. Biomed. Res. Int. 2013 (2013) 638043.

339. D.M. Dohan, J. Choukroun, A. Diss, S.L. Dohan, A.J. Dohan, J. Mouhyi, B. Gogly. Oral. Surg. Oral. Med. Oral. Pathol. Oral. Radiol. Endod. 101 (2006) e51-e55.

340. C.L. Wu, S.S. Lee, C.H. Tsai, K.H. Lu, J.H. Zhao, Y.C. Chang. Aust. Dent. J. 57 (2012) 207-212.

341. G. Marenzi, F. Riccitiello, M. Tia, A. di Lauro, G. Sammartino. BioMed. Res. Int. 2015 (2015) 369273.

342. D.M. Dohan Ehrenfest, A. Diss, G. Odin, P. Doglioli, M.P. Hippolyte, J.B. Charrier. Oral. Surg. Oral. Med. Oral. Pathol. Oral. Radiol. Endod. 108 (2009) 341-352.

343. D.M. Dohan Ehrenfest, M. Del Corso, A. Diss, J. Mouhyi, J.B. Charrier. J. Periodontol. 81 (2010) 546-555.

344. K.M. Galler, A.C. Cavender, U. Koeklue, L.J. Suggs, G. Schmalz, R.N. D’Souza. Regener. Med. 6 (2011) 191-200.

345. C.M. Yeh, J.P. Wang, S.C. Lo, W.C. Chan, M.Y. Lin. Biotechnol. Prog. 26 (2010) 
1001-1007.

346. S. Van, S.K. Das, X. Wang, Z. Feng, Y. Jin, Z. Hou, F. Chen, A. Pham, N. Jiang, S.B. Howell, L. Yu. Int. J. Nanomed. 5 (2010) 825-837.

347. J. A. Portilla-Arias, B. Camargo, M. Garcia-Alvarez, A. M. de Ilarduya,S. MunozGuerra. J. Biomater. Sci. Polym. Ed. 20 (2009) 1065-1079.

348. M. Matsusaki, H. Yoshida, M. Akashi. Biomaterials 28 (2007) 2729-2737.

349. S.F. Peng, M.T. Tseng, Y.C. Ho, M.C. Wei, Z.X. Liao, H.W. Sung. Biomaterials 32 (2011) 239-248.

350. M. Takehara, A. Hibino, M. Saimura, H. Hirohara. Biotechnol. Lett. 32 (2010) 1299-1303.

351. C.K. Tang, K.C. Sheng, D. Pouniotis, S. Esparon, H.Y. Son, C.W. Kim, G.A. Pietersz, V. Apostolopoulos. Vaccine 26 (2008) 3827-3834.

352. K. Tahara, S. Furukawa, H. Yamamoto, Y. Kawashima. Int. J. Pharm. 392 (2010) 311-313.

353. Z. Zheng, L. Zhang, L. Kong, A. Wang, Y. Gong, X. Zhang. J. Biomed. Mater. Res. A 89 (2009) 453-465.

354. S.S. Kim, M. Seo, J.W. Chung, S.Y. Kwon, Y.-S. Kim. J. Appl. Polym. Sci. 113 (2009) 1223-1231.

355. D. Galli, L. Benedetti, M. Bongio, V. Maliardi, G. Silvani, G. Ceccarelli, F. Ronzoni, S. Conte, F. Benazzo, A. Graziano, G. Papaccio, M. Sampaolesi, M.G. De Angelis. J. Biomed. Mater. Res. A 97 (2011) 118-126.

356. E. Varoni, E. Canciani, B. Palazzo, V. Varasano, P. Chevallier, L. Petrizzi, C. Dellavia, D. Mantovani, L. Rimondini. J. Oral. Implantol. 41 (2015) 626-631.

357. G.P. Nick J Walters, P.F. Ashley, A.M. Young, Monocalcium phosphate induces greater hydroxyapatite mineral formation than tricalcium phosphate on dental composites containing ع-poly-L-lysine. In TERMIS-WC 2015 (Tissue Engineering \& Regenerative Medicine International Society World Congress), Boston, MA, USA, 2015.

358. H. Yuan, K. Luo, Y. Lai, Y. Pu, B. He, G. Wang, Y. Wu, Z. Gu. Mol. Pharm. 7 (2010) 953-962.

359. H.C. Chiu, P. Kopeckova, S.S. Deshmane, J. Kopecek. J. Biomed. Mater. Res. 34 (1997) 381-392.

360. L. Chen, H. Tian, J. Chen, X. Chen, Y. Huang, X. Jing. J. Gene Med. 12 (2010) 6476

361. A.M. Pilbat, V. Ball, P. Schaaf, J.C. Voegel, B. Szalontai. Langmuir 22 (2006) 5753-5759.

362. H. Layman, M.G. Spiga, T. Brooks, S. Pham, K.A. Webster, F.M. Andreopoulos. Biomaterials 28 (2007) 2646-2654.

363. O. Karal-Yilmaz, N. Kayaman-Apohan, Z. Misirli, K. Baysal, B.M. Baysal. J. Mater. Sci. Mater. Med. 17 (2006) 213-227.

364. G. Pitarresi, F. Saiano, G. Cavallaro, D. Mandracchia, F.S. Palumbo. Int. J. Pharm. 335 (2007) 130-137.

365. N. Benkirane-Jessel, C.M. Palomares, F. Fioretti, Compound comprising alphamsh for use in endodontic regeneration. Google Patents: 2014.

366. R. Osorio, S. Sauro, T.F. Watson, M. Toledano. Int. Endod. J. 49 (2016) 874-883.

367. P. Rapta, K. Valachova, P. Gemeiner, L. Soltes. Chem. Biodivers. 6 (2009) 162-169.

368. X. Wang, J. Ji. Langmuir 25 (2009) 11664-11671.

369. M. Ravina, E. Cubillo, D. Olmeda, R. Novoa-Carballal, E. Fernandez-Megia, R. 
Riguera, A. Sanchez, A. Cano, M.J. Alonso. Pharm. Res. 27 (2010) 2544-2555.

370. G. Pasquinelli, C. Orrico, L. Foroni, F. Bonafe, M. Carboni, C. Guarnieri, S. Raimondo, C. Penna, S. Geuna, P. Pagliaro, A. Freyrie, A. Stella, C.M. Caldarera, C. Muscari. J. Anat. 213 (2008) 520-530.

371. A. Temiz, K.C. Kazikdas, B. Ergur, K. Tugyan, S. Bozok, D. Kaya, E. Guneli. Otolaryngol. Head Neck Surg. 143 (2010) 772-778.

372. B. Grigolo, G. Lisignoli, G. Desando, C. Cavallo, E. Marconi, M. Tschon, G. Giavaresi, M. Fini, R. Giardino, A. Facchini. Tissue Eng. Part C Methods 15 (2009) 647-658.

373. L. Pandis, B. Zavan, G. Abatangelo, S. Lepidi, R. Cortivo, V. Vindigni. J. Biomed. Mater. Res. A 93 (2010) 1289-1296.

374. B. Zavan, G. Abatangelo, F. Mazzoleni, F. Bassetto, R. Cortivo, V. Vindigni. Neurol. Res. 30 (2008) 190-196.

375. K.Y. Choi, H. Chung, K.H. Min, H.Y. Yoon, K. Kim, J.H. Park, I.C. Kwon, S.Y. Jeong. Biomaterials 31 (2010) 106-114.

376. D.A. Gianolio, M. Philbrook, L.Z. Avila, L.E. Young, L. Plate, M.R. Santos, R. Bernasconi, H. Liu, S. Ahn, W. Sun, P.K. Jarrett, R.J. Miller. Bioconjug. Chem. 19 (2008) 1767-1774.

377. P. Pirnazar, L. Wolinsky, S. Nachnani, S. Haake, A. Pilloni, G.W. Bernard. J. Periodontol. 70 (1999) 370-374.

378. A. Pilloni, S. Annibali, F. Dominici, C. Di Paolo, M. Papa, M.A. Cassini, A. Polimeni. Ann. Stomatol. (Roma) 2 (2011) 3-9.

379. K.M. Fawzy El-Sayed, M.A. Dahaba, S. Aboul-Ela, M.S. Darhous. Clin. Oral. Investig. 16 (2012) 1229-1236.

380. G. Gontiya, S.R. Galgali. J. Indian Soc. Periodontol. 16 (2012) 184-192.

381. A. Koshal, P. Patel, B. Robert, N. Peter Galgut. Prev. Dent. 2 (2007) 34-38.

382. A. Pistorius, M. Martin, B. Willershausen, P. Rockmann. Quintessence Int. 36 (2005) 531-538.

383. H. Jentsch, R. Pomowski, G. Kundt, R. Gocke. J. Clin. Periodontol. 30 (2003) 159-164.

384. F.L. Mesa, J. Aneiros, A. Cabrera, M. Bravo, T. Caballero, F. Revelles, R. G. del Moral, F. O'Valle. Histol. Histopathol. 17 (2002) 747-753.

385. M. de Araujo Nobre, N. Cintra, P. Malo. Int. J. Dent. Hyg. 5 (2007) 87-94.

386. A. Ballini, S. Cantore, S. Capodiferro, F.R. Grassi. Int. J. Med. Sci. 6 (2009) 65-71.

387. L. Vanden Bogaerde. Int. J. Periodontics Restorative Dent. 29 (2009) 315-323.

388. A. Johannsen, M. Tellefsen, U. Wikesjo, G. Johannsen. J. Periodontol. 80 (2009) 1493-1497.

389. M.A. Kosir, C.C. Quinn, W. Wang, G. Tromp. J. Surg. Res. 92 (2000) 45-52.

390. P.S. Chan, J.P. Caron, G.J. Rosa, M.W. Orth. Osteoarthritis Cartilage 13 (2005) 387-394.

391. P. du Souich, A.G. Garcia, J. Verges, E. Montell. J. Cell. Mol. Med. 13 (2009) 1451-1463.

392. C. Malavaki, S. Mizumoto, N. Karamanos, K. Sugahara. Connect. Tissue Res. 49 (2008) 133-139.

393. Y. Liu, S. Cai, X.Z. Shu, J. Shelby, G.D. Prestwich. Wound Repair. Regen. 15 (2007) 245-251.

394. K.Y. Chang, L.H. Hung, I.M. Chu, C.S. Ko, Y.D. Lee. J. Biomed. Mater. Res. A 92 (2010) 712-723. 
395. X.Z. Shu, S. Ahmad, Y. Liu, G.D. Prestwich. J. Biomed. Mater. Res. A 79 (2006) 902-912.

396. N. Sawatjui, T. Damrongrungruang, W. Leeanansaksiri, P. Jearanaikoon, S. Hongeng, T. Limpaiboon. Mater. Sci. Eng. C Mater. Biol. Appl. 52 (2015) 90-96.

397. W. Xia, P. Liu, J. Liu. Bioresour. Technol. 99 (2008) 6751-6762.

398. D.-H. Li, L.-M. Liu, K.-L. Tian, J.-C. Liu, X.-Q. Fan. Carbohydrate Polym. 67 (2007) 40-45.

399. C.J. Park, N.P. Gabrielson, D.W. Pack, R.D. Jamison, A.J. Wagoner Johnson. Biomaterials 30 (2009) 436-444.

400. M. Burkatovskaya, G.P. Tegos, E. Swietlik, T.N. Demidova, P.C.A, M. R. Hamblin. Biomaterials 27 (2006) 4157-4164.

401. L. Wu, H. Li, S. Li, X. Li, X. Yuan, X. Li, Y. Zhang. J. Biomed. Mater. Res. A 92 (2010) 563-574.

402. B.S. Liu, C.H. Yao, S.S. Fang. Macromol. Biosci. 8 (2008) 432-440.

403. A.K. Azab, B. Orkin, V. Doviner, A. Nissan, M. Klein, M. Srebnik, A. Rubinstein. J. Control. Release 111 (2006) 281-289.

404. J. Wang, S.S. Feng, S. Wang, Z.Y. Chen. Int. J. Pharm. 400 (2010) 194-200.

405. 0. Germershaus, S. Mao, J. Sitterberg, U. Bakowsky, T. Kissel. J. Control. Release 125 (2008) 145-154.

406. C.B. Woitiski, R.J. Neufeld, A.J. Ribeiro, F. Veiga. Acta Biomater. 5 (2009) 24752484.

407. J. Sarukawa, M. Takahashi, M. Abe, D. Suzuki, S. Tokura, T. Furuike, H. Tamura. J. Biomater. Sci. Polym. Ed. 22 (2011) 717-732.

408. B.M. Chesnutt, Y. Yuan, K. Buddington, W.O. Haggard, J.D. Bumgardner. Tissue Eng. Part A 15 (2009) 2571-2579.

409. L.A. Pfister, M. Papaloizos, H.P. Merkle, B. Gander. J. Biomed. Mater. Res. A 80 (2007) 932-937.

410. E.M. Decker, C. von Ohle, R. Weiger, I. Wiech, M. Brecx. J. Periodontal. Res. 40 (2005) 373-377.

411. H. Sano, K. Shibasaki, T. Matsukubo, Y. Takaesu. Bull. Tokyo Dent. Coll. 43 (2002) 75-82.

412. H. Sano, K.-I. Shibasaki, T. Matsukubo, Y. Takaesu. Bull. Tokyo Dent. Coll. 42 (2001) 243-249.

413. H.J. Busscher, E. Engels, R.J.B. Dijkstra, H.C. Van Der Mei. Eur. J. Oral Sci. 116 (2008) 493-495.

414. N. Mohire, A. Yadav. Indian J. Dent. Res. 21 (2010) 380-384.

415. S.E. Elsaka. Quintessence Int. 43 (2012) 603-613.

416. J. Wang, J. de Boer, K. de Groot. J. Dent. Res. 83 (2004) 296-301.

417. A. Shrestha, S. Friedman, A. Kishen. J. Dent. Res. 90 (2011) 1346-1351.

418. T. Jiang, S.G. Kumbar, L.S. Nair, C.T. Laurencin. Curr. Top. Med. Chem. 8 (2008) 354-364.

419. K.M. Galler, R.N. D'Souza, J.D. Hartgerink, G. Schmalz. Adv. Dent. Res. 23 (2011) 333-339.

420. C.S. Tan, A. Jejurikar, B. Rai, T. Bostrom, G. Lawrie, L. Grondahl. J. Biomed. Mater. Res. A 91 (2009) 866-877.

421. E. Marsich, M. Borgogna, I. Donati, P. Mozetic, B.L. Strand, S.G. Salvador, F. Vittur, S. Paoletti. J. Biomed. Mater. Res. A 84 (2008) 364-376.

422. H.H. Xu, M.D. Weir, C.G. Simon. Dent. Mater. 24 (2008) 1212-1222.

423. G. Orive, M. De Castro, H.J. Kong, R.M. Hernandez, S. Ponce, D.J. Mooney, J.L. 
Pedraz. J. Control. Release 135 (2009) 203-210.

424. N.C. Hunt, R.M. Shelton, L. Grover. Biotechnol. J. 4 (2009) 730-737.

425. X.Y. Liu, J.M. Nothias, A. Scavone, M. Garfinkel, J.M. Millis. Asaio J. 56 (2010) 241-245.

426. S. Giovagnoli, T. Tsai, P.P. DeLuca. AAPS PharmSciTech 11 (2010) 212-220.

427. S.M. Jay, B.R. Shepherd, J.W. Andrejecsk, T.R. Kyriakides, J.S. Pober, W.M. Saltzman. Biomaterials 31 (2010) 3054-3062.

428. J. Qi, A. Chen, H. You, K. Li, D. Zhang, F. Guo. Biomed. Mater. 6 (2011) 015006.

429. X. Meng, P. Li, Q. Wei, H.X. Zhang. Pharm. Dev. Technol. 16 (2011) 22-28.

430. C.R. Wittmer, J.A. Phelps, C.M. Lepus, W.M. Saltzman, M.J. Harding, P.R. Van Tassel. Biomaterials 29 (2008) 4082-4090.

431. S.S. Olmez, P. Korkusuz, H. Bilgili, S. Senel. Pharmazie 62 (2007) 423-431.

432. J.W. Lee, Y.J. Park, S.J. Lee, S.K. Lee, K.Y. Lee. Biomaterials 31 (2010) 5545-5551.

433. K. Ishikawa, Y. Miyamoto, M. Kon, M. Nagayama,K. Asaoka. Biomaterials 16 (1995) 527-532.

434. K. Ishikawa, Y. Miyamoto, M. Takechi, T. Toh, M. Kon, M. Nagayama,K. Asaoka. J. Biomed. Mater. Res. 36 (1997) 393-399.

435. R.M. Morrow, C.E. Brown, B.E. Stansbury, J.A. deLorimier, J.M. Powell, K.D. Rudd. J. Prosthetic Dent. 25 (1971) 556-566.

436. V. Nandini, K. Venkatesh, K. Nair. J. Conserv. Dent. 11 (2008) 37-41. 
